\title{
The effectiveness of policies for addressing Covid-19 impacts on wildlife conservation in Vietnam
}

Trinh Thi Mai

Pham Thu Thuy

Pham Van Thong

Cao Nhat Long

Tran Ngoc My Hoa

Nguyen Thi Van Anh

Nguyen Thi Thuy Anh

Tang Thi Kim Hong

Nguyen Van Thai

Russell J. Gray 

Working Paper 276

\title{
The effectiveness of policies for addressing Covid-19 impacts on wildlife conservation in Vietnam
}

\author{
Trinh Thi Mai \\ Save Vietnam's Wildlife -SVW \\ Pham Thu Thuy \\ Center for International Forestry Research- CIFOR \\ Pham Van Thong \\ Save Vietnam's Wildlife -SVW \\ Cao Nhat Long \\ Save Vietnam's Wildlife -SVW \\ Tran Ngoc My Hoa \\ Center for International Forestry Research- CIFOR \\ Nguyen Thi Van Anh \\ Vietnam National University \\ Nguyen Thi Thuy Anh \\ Diplomatic Academy of Vietnam \\ Tang Thi Kim Hong \\ Nong Lam University \\ Nguyen Van Thai \\ Save Vietnam's Wildlife -SVW \\ Russell J. Gray \\ Save Vietnam's Wildlife -SVW
}


Working Paper 276

(C) 2021 Center for International Forestry Research

(c) (i) Content in this publication is licensed under a Creative Commons Attribution 4.0 International (CC BY 4.0), http://creativecommons.org/licenses/by/4.0/

DOI: $10.17528 /$ cifor/008316

Trịnh TM, Phạm TT, Phạm VT, Cao NL, Tran NMH, Nguyen TVA, Nguyen TTA, Tang TKH, Nguyen VT and Russell JG. 2021. The effectiveness of policies for addressing Covid-19 impacts on wildlife conservation in Vietnam. Working Paper 276. Bogor, Indonesia: CIFOR.

\section{CIFOR}

Jl. CIFOR, Situ Gede

Bogor Barat 16115

Indonesia

$\mathrm{T}+62(251) 8622-622$

$\mathrm{F}+62(251) 8622-100$

E cifor@cgiar.org

\section{cifor.org}

We would like to thank all funding partners who supported this research through their contributions to the CGIAR Fund. For a full list of the 'CGIAR Fund' funding partners please see: http://www.cgiar.org/our-funders/

Any views expressed in this publication are those of the authors. They do not necessarily represent the views of CIFOR, the editors, the authors' institutions, the financial sponsors or the reviewers. 


\section{Contents}

Abbreviations

Acknowledgements $\quad$ v

Executive summary

1 Introduction $\quad 1$

2 Methods $\quad 3$

3 Results 4

3.1 Covid-19 impacts on wildlife conservation in Vietnam 4

3.2 Policies and measures in response to Covid-19

$\begin{array}{lll}3.3 & \text { Effectiveness of policies and measures } & 9\end{array}$

4 Discussion and recommendations $\quad 12$

4.1 Holistic and cross-sectoral approaches for sustainable wildlife management 12

$\begin{array}{lll}4.2 & \text { Enhance wildlife trade monitoring } & 12\end{array}$

$\begin{array}{lll}4.3 & \text { Diversify funding sources for both state and non-state actors } & 14\end{array}$

4.4 Post- Covid-19 recovery plans and preventive measures to reduce the risk of future
disease outbreaks

$\begin{array}{lr}\text { References } & 18\end{array}$

\section{List of figures and tables}

\section{Figures}

1 Trends in international trade of CITES listed species exported from Vietnam from 1990-2020. The data shows sudden, sharp falls in exports of birds, reptiles, mammals and undocumented species in 2020; while declines in bird and amphibian exports are apparent in previous years. Data source: https://trade.cites.org/.

2 Numbers of pangolins rescued from 2015-2021 by Save Vietnam's Wildlife and the Cuc Phuong National Park Carnivore and Pangolin Conservation Programme. Data source: Save Vietnam's Wildlife (2021)

3 Numbers of cases involving wildlife violations in the top three illegal wildlife trade hotspots in Asia (EIA 2021)

4 A) CITES data on numbers of fish, mammal and reptile products reported by importers and Vietnam from 2010-2020; B) EIA data on fish, mammals and reptiles exported from Vietnam from 2010-2020 as reported by importers and Vietnam. Data sources: EIA (2021), CITES (2021)

\section{Tables}

1 Institutional setting for wildlife conservation and Covid-19 responses 7

2 Funding sources for wildlife conservation in Vietnam 14 


\section{Abbreviations}

EID Emerging infectious disease

IWT Illegal wildlife trade

IUCN International Union for Conservation of Nature

CITES Convention on International Trade in Endangered Species

HS Codes Harmonized System Codes

TCM Traditional Chinese medicine 


\section{Acknowledgements}

This study was funded by the Covid-19 Hub, the CGIAR Research Program on Forests, Trees and Agroforestry (FTA), the United States Agency for International Development (USAID), and the International Food Policy Research Institute (IFPRI). We would like to express our special thanks to all experts participating in the national policy dialogue on "Assessing the effectiveness of wildlife conservation policies, lessons learned and recommendations for 2021-2030, with a vision to 2050" held on 13 October 2021. 


\section{Executive summary}

The Covid-19 pandemic has stirred up global and national concerns over human-wildlife interactions, unsustainable and illegal wildlife trade, ecosystem degradation and the need to transform both policies and practices in achieving effective conservation outcomes. As new policies on post-Covid-19 recovery are being developed, global and national policymakers and practitioners call for scientific and rigorous assessments on the effectiveness of past and current wildlife conservation policies and projects, and the impacts Covid-19 is having on them, to provide inputs for evidence-based decision-making processes. Our paper is one of many efforts aiming to respond to this call.

Based on a literature review, case study approach, and national policy dialogue, this paper aims to understand the impacts of Covid-19 on wildlife conservation, opportunities for and challenges to enhancing the effectiveness of current and future conservation schemes, and to propose recommendations for post-pandemic conservation actions.

Our paper shows that Covid-19 has had mixed impacts on wildlife conservation, both globally and in Vietnam. While positive signals have been documented, such as increasing political will among policymakers for strengthening wildlife conservation policies in Vietnam and securing more bilateral agreements to help fund wildlife conservation and efforts to address illegal wildlife trading, our study shows illegal wildlife trade remains prevalent across the nation. Challenges in monitoring cross-border wildlife trade and a fall in funding for conservation also hamper implementation of such policies. Policymakers must account for all stakeholder concerns, nuanced as they may be, when making decisions on prohibitions of any kind. Leaders and decision makers must act intently and proportionately towards pandemic prevention by heeding the advice of experts in zoonotic disease spillover events, and conservationists that set the groundwork for protecting the natural world by monitoring biodiversity and understanding drivers of wildlife trade. 


\section{Introduction}

Wildlife trade, legal and illegal, is one of the most profitable industries in the world, generating billions of dollars for wildlife traders (Fukushima et al. 2020). Illegal wildlife trade is a major threat to global biodiversity (Harrison et al. 2016; Gray 2018; Symes et al. 2018), hampers effective wildlife conservation in Southeast Asia (Nijman 2010), and poses a severe threat to human health (Van Viet et al. 2017; Jayaram et al. 2020). Examples of dangerous zoonotic diseases transferred from wildlife include Ebola, H5N1, SARS, MERS and AIDS (Rupani et al. 2020). While there is no concrete evidence of the Covid-19 virus having been transferred from wildlife, many studies have suggested that bats, snakes or pangolins can be feasible carriers of the closest viral strains (Kumar et al. 2020). Approximately $60 \%$ of such infectious viral diseases have come from animals, and nearly $70 \%$ of these can be transferred to humans (Jones et al. 2008; Hu et al. 2017; Can et al. 2019; Chakraborty and Maity 2020). Covid-19 infections have been found in a wide variety of mammal species, including bats, rodents, felids, canines, mustelids and primates (Melin et al. 2020; Xu et al. 2020; Hobbs and Reid 2021; Sharun et al. 2021), and many other species containing the ACE2 protein receptor (Zeiss et al. 2021). Additionally, there have been several records of Covid-19 infections in domestic and farmed livestock (Kumar et al. 2020; Leroy et al. 2020; McNamara et al. 2020; Sharun et al. 2021).

Wildlife trade continues at high levels today, despite increased efforts to control illegal activities (Blair et al. 2017). The global conservation community has high hopes that the Covid-19 pandemic might be a wakeup call for both policymakers and practitioners in transforming their wildlife conservation policies and projects towards a more holistic approach in fully recognizing and addressing both ecosystem and human needs and interactions (TRAFFIC 2020). Previous studies have shown Covid-19 having mixed impacts on wildlife conservation. Researchers have recorded some short-term ecological benefits resulting from reduced human activity, such as a noticeable decrease in wildlife road mortalities (Driessen 2021; Shilling et al. 2021), large-scale land use change (Schrimpf et al. 2021), evidence of disturbance-sensitive species fearlessly entering urban areas (Silva-Rodríguez et al. 2021), researchers being able to quantify the effects of constant human activity on wildlife communities (Rutz et al. 2020), frequent access and improvement of citizen science platforms such as eBird and iNaturalist (Sánchez-Clavijo et al. 2021) and decreased $\mathrm{CO}_{2}$ levels across the world (Lui et al. 2020). Even behavioural changes in zoo animals were noticeable during lockdown periods, such as wider use of enclosures, increasingly positive social interactions, and less stress-induced alert behaviour (Williams et al. 2021).

However, these victories are likely to be quickly and aggressively reversed with loosened travel restrictions. There is mounting evidence of Covid-19 having adverse impacts on biodiversity, especially through increased numbers of poaching incidents in protected areas in Asia and Africa due to influxes of unemployed people returning to their home countries and provinces as wildlife-tourismbased incomes vanish (Jakarta Post 2020; QUARTZ 2020; Roth 2020), making wild animals a more viable option for food and income (DW 2020; Ghosal and Casey 2020; Maron, 2020). Covid-19 also poses challenges to monitoring cross-border and online wildlife trade (Basu et al. 2020). Market demand in cyber trade sectors has increased in the last 5 years (Roberts and Hernandez-Castro 2017; Xiao, Guan and Xu 2017; Siriwat and Nijman 2018; Morcatty et al. 2021). Numbers of wildlife interceptions via human border-crossings may have been reduced due to lockdowns and international travel bans, which means air and sea ports-of-entry have been provided with a unique opportunity during the pandemic to become primary pinch-points of the illegal wildlife trade. However, due to undistilled Harmonized System codes (HS Codes) used to classify goods, and ineffective methods and resources available to identify animal parts, many transboundary trade records remain unspecific and unhelpful in documenting goods, which may be contributing to the unsustainable harvest of specific species (Andersson et al. 2021). 
Moreover, Covid-19 has also led to reduced availability of funding for conservation, which is often generated from wildlife tourism (Lindsey et al. 2007, di Minin et al. 2016; World Travel and Tourism Council 2019; Rupani et al. 2020). Many zoos are currently out of business or going bankrupt due to prolonged travel restrictions and business lockdowns aimed at preventing the spread of Covid-19. They completely lack needed support to keep animals fed, enclosures maintained, and staff employed (Loeb 2021). Further, due to job losses and lost incomes as a result of Covid-19, forest dependent peoples might have to increase their exploitation of forest resources (Luo et al. 2020; Public Security News 2020; The Laborer Newspaper 2020). Poverty and food shortages bring additional threats to conservation, including poaching (di Minin et al. 2016). Covid-19 restrictions have inhibited effective means of hands-on, in-person education and capacity building efforts for new conservation scientists (Corlett et al. 2020).

Asian countries are important global hubs for wildlife trade (BBC News 2021). China, Malaysia, Vietnam and Indonesia are the main exporters in Asia, while the European Union and Japan are the largest importers (Nijman 2010). Since Covid-19, increasing numbers of studies have documented the pandemic's impacts on wildlife conservation in Asia (Md-Zain et al. 2020; Sciortino and Saini 2020; van Staden 2020; USAID 2021). These studies share a common finding on the need to address knowledge gaps in understanding both the short- and long-term impacts of the Covid-19 pandemic on wildlife conservation. Using Vietnam as a case study, this paper examines these impacts, as well as opportunities and challenges for implementing and monitoring wildlife conservation policies, and proposes policy recommendations for post-pandemic recovery plans. Vietnam was chosen as our case study for different reasons. First, the country has a high biodiversity index and is currently one of the main hubs for illegal wildlife trade and poaching in Southeast Asia (USAID Learns 2020). Second, despite a strong political commitment towards sustainable wildlife management, analyses of the effectiveness of policies and measures for conserving wildlife are scarce and limited, particularly since Covid-19 (USAID Learns 2020). As the country is currently developing its national biodiversity conservation strategy, policymakers are calling for additional scientific research on wildlife conservation in response to Covid-19 as important input for decision making (Hoang 2021a). 


\section{Methods}

Two research methods were employed in this study.

\section{A literature review}

Through Google Scholar searches in both English and Vietnamese, we reviewed academic and grey literature on the impacts on Covid-19 on wildlife conservation both globally and in Vietnam, as well as lessons learned from and the effectiveness of existing wildlife conservation policies and projects. Our searches used a range of keywords on the following topics: Covid-19 impacts on wildlife, policy reforms for wildlife/conservation recovery during and after the pandemic, and effectiveness of wildlife conservation policies. We also reviewed newspaper reports and available technical reports and working papers on these topics produced by donors, civil society organizations, and academics in both English and Vietnamese.

\section{Policy dialogue}

We held a policy dialogue on 13 October 2021 entitled "Assessing the effectiveness of wildlife protection policies, lessons learned and recommendations for 2021-2030, with a vision to 2050" to ascertain stakeholders' perspectives of Covid-19 impacts on conservation in Vietnam, the effectiveness of current wildlife conservation policies, and opportunities and challenges for sustainable wildlife management. More than 100 participants representing government agencies, donors, civil society organizations, academia, the private sector, international NGOs and the media took part in the event and discussed the studied topics. 


\section{Results}

\subsection{Covid-19 impacts on wildlife conservation in Vietnam}

\subsubsection{Fall in undocumented species in cross-border trade}

Biodiversity loss through transboundary trade, mostly to and from China, is a significant driver of extinction pressures on Vietnamese wildlife (Lin 2005; Patel et al. 2015). During the 20th century, Vietnam transitioned from exploiting domestic wildlife to becoming a nexus in the international wildlife trade chain between Laos, Cambodia and China. Due to the Covid-19 outbreak, China closed its borders in March 2020 and released a CITES declaration saying it would ban all wildlife exploitation and wildlife farms. This has impacted significantly on Vietnam's wildlife-based revenues from both legal and illegal exports, with marked decreases in exports, especially those representing seizures or undocumented species, being immediately visible in CITES data (Figure 1). The CITES data also provide insights into trade developments in undocumented species (either from seizures, unknown parts, or poor record keeping), which grew steadily to exceed all other animal classes in 2014, and then fell below each of them in 2020, likely reflecting the effects of tightened restrictions.

Numbers of confiscated animals, especially highly-trafficked species, also fell significantly. According to animal rescue records from Save Vietnam's Wildlife, numbers fell sharply in 2020 and 2021 compared to previous years, with a markedly sharp decrease in numbers of pangolins rescued after 2019 (Figure 2).

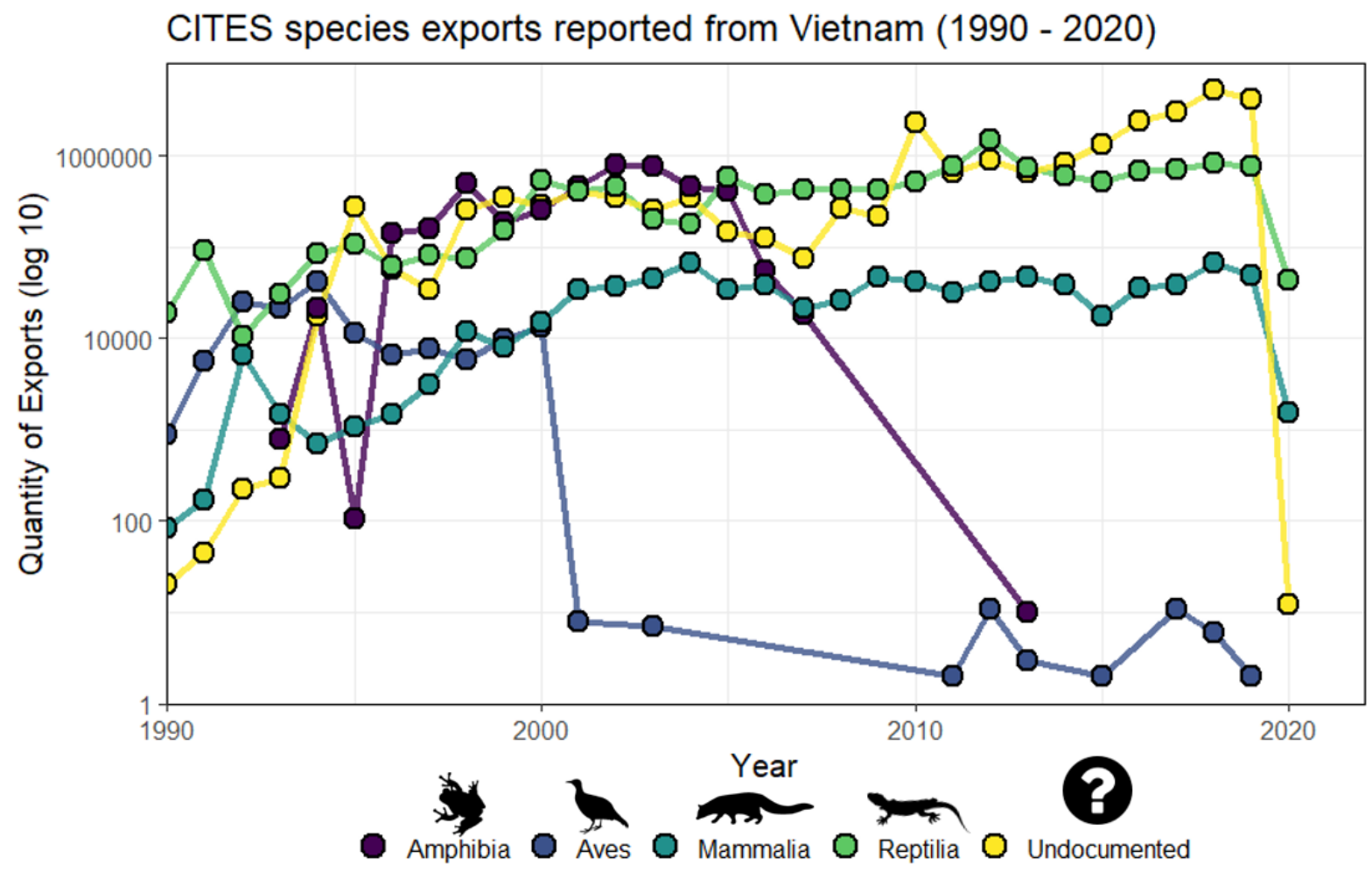

Figure 1. Trends in international trade of CITES listed species exported from Vietnam from 1990-2020. The data shows sudden, sharp falls in exports of birds, reptiles, mammals and undocumented species in 2020; while declines in bird and amphibian exports are apparent in previous years.

Source: https://trade.cites.org/. 


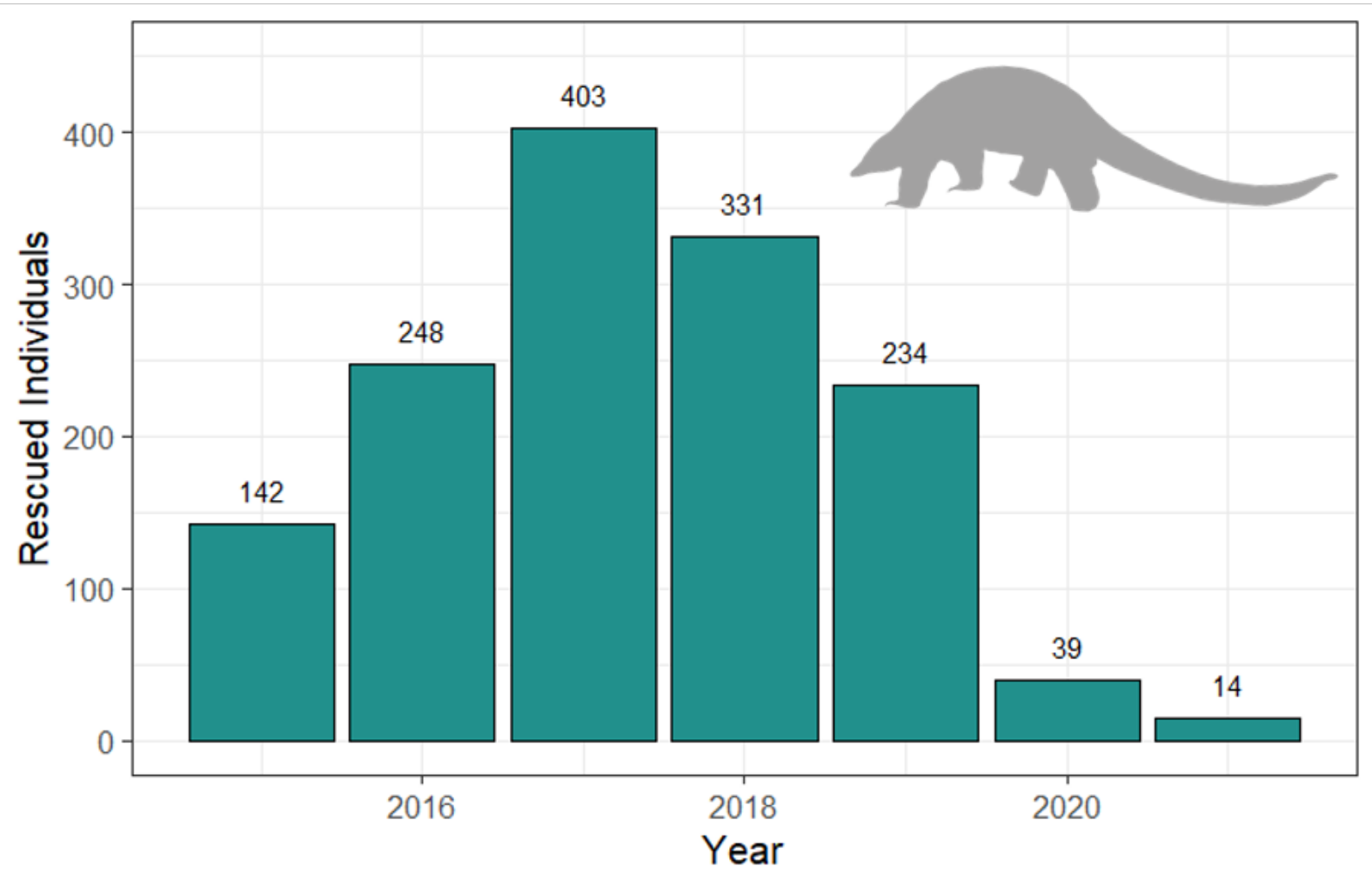

Figure 2. Numbers of pangolins rescued from 2015-2021 by Save Vietnam's Wildlife and the Cuc Phuong National Park Carnivore and Pangolin Conservation Programme.

Source: Save Vietnam's Wildlife (2021)

In Vietnam, pangolins are mainly captured in-country or transported from Laos and Cambodia. The fall in numbers of rescued animals is likely a reflection of the closures between adjacent Southeast Asian nations, and the primary export destination, China.

Additionally, a total of 2,909 , or around $50 \%$ of wildlife violation cases in 2020 - mostly involving primates, bears and tigers - were reported through a hotline for citizens to report wildlife crimes (ENV 2021). This could be an indication that the public has become more vigilant and more involved in mitigating wildlife crimes.

\subsubsection{Increases in wildlife poaching and trade (both online and offline) in Vietnam}

While border closures may reduce numbers of animals traded transnationally, there is evidence of illegal poaching and illegal wildlife trade being prevalent throughout Vietnam since Covid-19 with studies in Quang Ngai (Thai 2021), Nghe An (Hong 2018; Binh 2021; Doan 2021), Ha Tinh (Le 2021), Lam Dong (Nhat 2018; Ngoc 2020; Duc 2021), Kon Tum (Tran 2010), Hanoi (Man 2021), Thanh Pho Ho Chi Minh (Phu 2020b), Long An (Lang Son News 2020), Da Nang (Thien 2020), Hung Yen and Lang Son (Phu 2020c), Son La and Quang Tri (Phu 2020a), Dak Nong and Quang Nam (Hai 2018; Phu 2019), Dak Lak (Quoc 2020), Dong Nai (Ha 2020), Binh Phuoc (Pham 2021), Quang Binh (Tam 2020) and Hai Phong, Thai Nguyen and Quang Ninh (Ly 2021). While local villagers have been seen as perpetrators (Phu 2019) earlier evidence shows wildlife trade value chains being complex, and those capturing its benefits not being local people (Pham et al. 2018a, 2018b, 2018c). Local people without stable jobs go to the forest to hunt and trap wild animals for consumption, as documented in Binh Phuoc and Son La provinces (Pham 2021a; Pham et al. 2021). 
The trade in wildlife as pets or wild meat also takes place via the internet in Vietnam (D 2018; Nguyen, 2020a; Phu 2020d; Manh 2021). In 2019 alone, the Wildlife Protection Department recorded more than 2,400 cases of wildlife advertising on Facebook, YouTube, Zalo, TikTok and other sites (Thien 2020). This number showed no sign of decreasing in the early months of 2020, with 424 violations by the end of April (Thien 2020). Online transactions are complex and difficult to detect in Vietnam as they usually involve closed groups using characters or codes to communicate to avoid the attention of the authorities (BBC News 2021). A quick survey by PanNature also confirmed that, both before and after the issuance of Directive No. 29/CT-TTg on Urgent Solutions for Wildlife Management, the trade in wildlife products in many localities remained unchanged, with wildlife markets still operating openly and even trading rare and protected animals (PanNature 2021).

Moreover, there is an increasing belief that animal trafficking will bounce back or even increase to its pre-Covid-19 levels as restrictions are lifted. This was the case with the SARS epidemic in the early 2000s, and evidence is already mounting to make this case (Anh 2021).

\subsubsection{Less funding for wildlife conservation}

Falling earnings from tourism threaten millions, severely impacting the livelihoods of the poorest people. In low income countries, for decades programmes have been aimed at converting hunters to conservationists and ecotourism operators by showing them the value of living wildlife (Gibson and Marks 1995; Batiran and Fisher 2020). Covid-19 has led to sharp reductions in funding for wildlife conservation, particularly in protected areas (Hockings et al. 2020). Tourism accounted for approximately 10\% of GDP in Vietnam (World Bank 2019), but is also the economic sector suffering the highest losses due to Covid-19 (Tien et al. 2020). Ecotourism is seen as a means for sustainable development and provides opportunities for local communities to be less dependent on natural resources. Education and awareness-raising activities have encouraged the establishment of community conservation and anti-poaching teams, which served to improve local people's livelihoods and provide them with sustainable alternative income sources. However, Covid-19 travel restrictions have prevented this industry from functioning and thriving, and unfortunately, until now, there has been no aid policy to support the sector's recovery. Directors of several national parks and protected areas participating in our policy dialogue said that ecotourism revenues had fallen by more than $90 \%$ during the pandemic, causing major challenges for them to fund staff and conservation activities. Similarly, many rescue centres in Vietnam are facing funding deficits in maintaining their daily operations (Hoang 2021c).

\subsubsection{Impacts on wildlife farms}

Most people participating in our policy dialogue felt that wildlife farming in Vietnam is currently unsustainable, due to a lack of regulatory mechanisms, poor animal welfare conditions and little to no veterinary care, which lead to high mortality rates and wild-caught animals often being used to supplement earnings illegally. Many rescued animals are badly injured, with almost no chance of being returned to the wild (BBC News 2021). Across southern Vietnam, 4,099 active farming operations, stocking an estimated one million wild animals (including, rodents, primates, civets, wild boar, snakes, deer, crocodiles and softshell turtles) have been recorded (Walzer 2020). These farming operations supply wild animals - predominantly for meat - to urban wild meat restaurants that serve increasingly affluent populations, while simultaneously supplying international market demand. Wildlife is often stressed and kept in cramped conditions along with other animals introduced from a variety of sources, which increases the likelihood of coronavirus transmission (Nguyen 2020b).

Research by Save Vietnam's Wildlife (forthcoming) found that Covid-19 has had a severe impact on civet coffee farms in Vietnam, with some losing up to $80-90 \%$ of their profits, as international tourists had made up the primary consumer base. Research by Pham et al. (2021) also shows wildlife farm owners in the south, including those farming wild meat, being unwilling to close their businesses despite operating illegally. Though some farm owners reported a decrease in value in civet meat, both studies show demand for wild meat remaining high throughout the pandemic. 


\subsubsection{Covid-19 impacts on consumer perceptions}

In 2020, an investigation by WWF on people's perspectives regarding Covid-19 showed $88 \%$ of people in Vietnam being worried about the pandemic's impacts (WWF 2021). More than $80 \%$ of Vietnamese respondents believed closing wildlife markets and imposing bans on wildlife hunting were essential to stop future pandemics (WWF 2021). However, around 14\% said they would still buy wild animal products in the future. This shows challenges remain on the demand side.

\subsection{Policies and measures in response to Covid-19}

Covid-19 has created favourable conditions for the conservation community to urge the Government of Vietnam to strengthen its wildlife conservation policies. In July 2020, in response to a proposal from the conservation community, the Prime Minister of Vietnam issued Directive 29/CT-TTg on Urgent Solutions for Wildlife Management. The directive was aimed at increasing patrolling and resources allocated to prevent illegal trade and exploitation of wildlife in ensuring Vietnam's commitments under the Convention on Biological Diversity (CBD) and the Convention on International Trade in Endangered Species of Wild Fauna and Flora (CITES). The Prime Minister also issued Official Letter No. 1744/VPCP-KGVX dated 6 March 2020 directing consideration for bans on wildlife trade and consumption. At the national level, the two ministries with biodiversity and wildlife conservation mandates - the Ministry of Agriculture and Rural Development (MARD) and the Ministry of Natural Resources and Environment (MONRE) - are devoting efforts to refining future pathways for sustainable wildlife management in Vietnam, while at the provincial level, provincial people's committees are actively complying with central government guidelines (Table 1).

Table 1. Institutional setting for wildlife conservation and Covid-19 responses

\begin{tabular}{ll}
\hline Agencies & Tasks and activities \\
\hline NATIONAL AGENCIES \\
\hline Cross \\
ministry & $\begin{array}{l}\text { In March 2021, the Government of Vietnam and international organizations and } \\
\text { domestic partners signed the One Health Partnership Framework for the prevention and } \\
\text { control of zoonotic diseases during the 2021-2025 period; } \\
\text { Five ministries and } 38 \text { international and domestic development partners have signed the } \\
\text { One Health Partnership Framework Agreement on Animal-to-Human Disease Control } \\
\text { (MSK). This framework aims to strengthen multi-sectoral coordination, especially close } \\
\text { coordination between MARD, MONRE and the Ministry of Health; } \\
\text { The parties coordinate and agree on how to intervene and handle epidemics when } \\
\text { they occur, and together share good practice dialogues and policy dialogues related to } \\
\text { zoonoses. More specifically, the MSK approach would strengthen control of human } \\
\text { diseases and pathogens of animal origin; control pandemic influenza of animal origin; } \\
\text { control rabies; control antibiotic resistance; control agents in the environment that have } \\
\text { the potential to affect human health; and increase mobilization and mobilize resources } \\
\text { for the prevention of animal-to-human epidemics; } \\
\text { Review and research the assessment of pathogens that interact between humans, animals } \\
\text { and the environment and strengthen intersectoral coordination and implementation of } \\
\text { mitigation measures for zoonotic diseases. }\end{array}$ \\
\hline
\end{tabular}


Table 1: Continue

\begin{tabular}{|c|c|}
\hline Agencies & Tasks and activities \\
\hline MONRE & $\begin{array}{l}\text { Promotes the implementation of documents relating to wildlife protection including: the } \\
\text { Law on Biodiversity; National Strategy on Biodiversity to } 2020 \text { with Vision to 2030; } \\
\text { National Plan on Biodiversity; Programme on Conservation of Endangered, Precious } \\
\text { and Rare Species prioritized for protection; and improving the Law on Environmental } \\
\text { Protection; } \\
\text { Issued Document No. 679/BTNMT-TCMT to ministries, ministerial-level agencies and } \\
\text { provincial government agencies to strengthen management of wild animals and control } \\
\text { illegal captive breeding, trading and consumption; } \\
\text { Issued Official Letter No. 379/BTNMT-TCMT to ministries, ministerial-level agencies, } \\
\text { governmental agencies, provincial people's committees and centrally-run cities on } \\
\text { promoting the control of trade and consumption of endangered wild animals and the } \\
\text { release of invasive alien species. Many ministries, sectors and localities have given } \\
\text { urgent and timely instructions to help control these situations; } \\
\text { Directs media agencies, departments, branches and units to intensify propaganda and } \\
\text { dissemination of the law and raise people's awareness of the need to not hunt, trade, } \\
\text { captive-breed or consume wildlife illegally, and of the risk of disease transmission } \\
\text { from consumption and contact with wild animals, with the aim of avoiding risks to } \\
\text { biodiversity conservation and human health. }\end{array}$ \\
\hline MARD & $\begin{array}{l}\text { - Has prime responsibility and coordinates with other ministries, including MONRE, the } \\
\text { Ministry of Police, Ministry of Information and Communication and relevant ministries } \\
\text { and agencies to develop the Prime Minister's directive on banning the sale, purchase and } \\
\text { consumption of wildlife; } \\
\text { The General Department of Forestry issued document No. 162/TCLN-CTVN to instruct } \\
\text { all provincial Departments of Agriculture and Rural Development (DARDs) to inspect } \\
\text { and handle illegal wild animal import, storage, processing and trading activities as a } \\
\text { matter of urgency, and tighten controls at borders, trails and corridors to prevent wildlife } \\
\text { being smuggled into the country; } \\
\text { Works with law enforcement agencies: forest rangers, market managers, customs, border } \\
\text { guards and police to strengthen intersectoral coordination, regularly inspect restaurants } \\
\text { and business establishments, prevent wildlife trading at animal markets and strictly } \\
\text { enforce laws on the protection of wild animals; } \\
\text { Directs and guides wildlife breeding establishments to strengthen quarantine and } \\
\text { disinfection, limit contact with wild animals, and regularly communicate with their } \\
\text { specialized management agencies, and requires provinces to record information on } \\
\text { disease outbreaks and infections; } \\
\text { Directed the Department of Animal Health to coordinate with competent agencies of the } \\
\text { Ministry of Health to review, appraise, evaluate and issue a decision to recognize testing } \\
\text { capacity, and to screen and confirm the SARS-CoV-2 virus that causes Covid-19 in } \\
\text { humans for the laboratory system of the Department of Animal Health. }\end{array}$ \\
\hline $\begin{array}{l}\text { Ministry of } \\
\text { Health }\end{array}$ & $\begin{array}{l}\text { Is requesting the Ministry of Agriculture and Rural Development to direct the } \\
\text { Department of Animal Health to review and improve capacity for Realtime RT-PCR } \\
\text { Covid-19 testing, and prepare equipment, facilities, human resources and biological } \\
\text { products to support the health sector in testing on a large scale in case of necessity. }\end{array}$ \\
\hline \multicolumn{2}{|c|}{ PROVINCIAL AGENCIES } \\
\hline DARDs & $\begin{array}{l}\text { - Strengthen the control of domestic wildlife transportation; } \\
\text { Direct the Forest Protection Department to stop certifying listed forest products and the } \\
\text { transporting of wild animal products out of the locality until further notice; } \\
\text { - Strengthen management of wildlife farming, processing and trading activities. In } \\
\text { cases where wild animals are found to be infected with infectious diseases, zoning and } \\
\text { handling should take place in accordance with the law on veterinary medicine; } \\
\text { Disseminate information to relevant organizations and individuals, and implement the } \\
\text { Prime Minister's directive in Official Dispatch No. 05/CT-TTg on the Import Ban. }\end{array}$ \\
\hline
\end{tabular}


Table 1: Continue

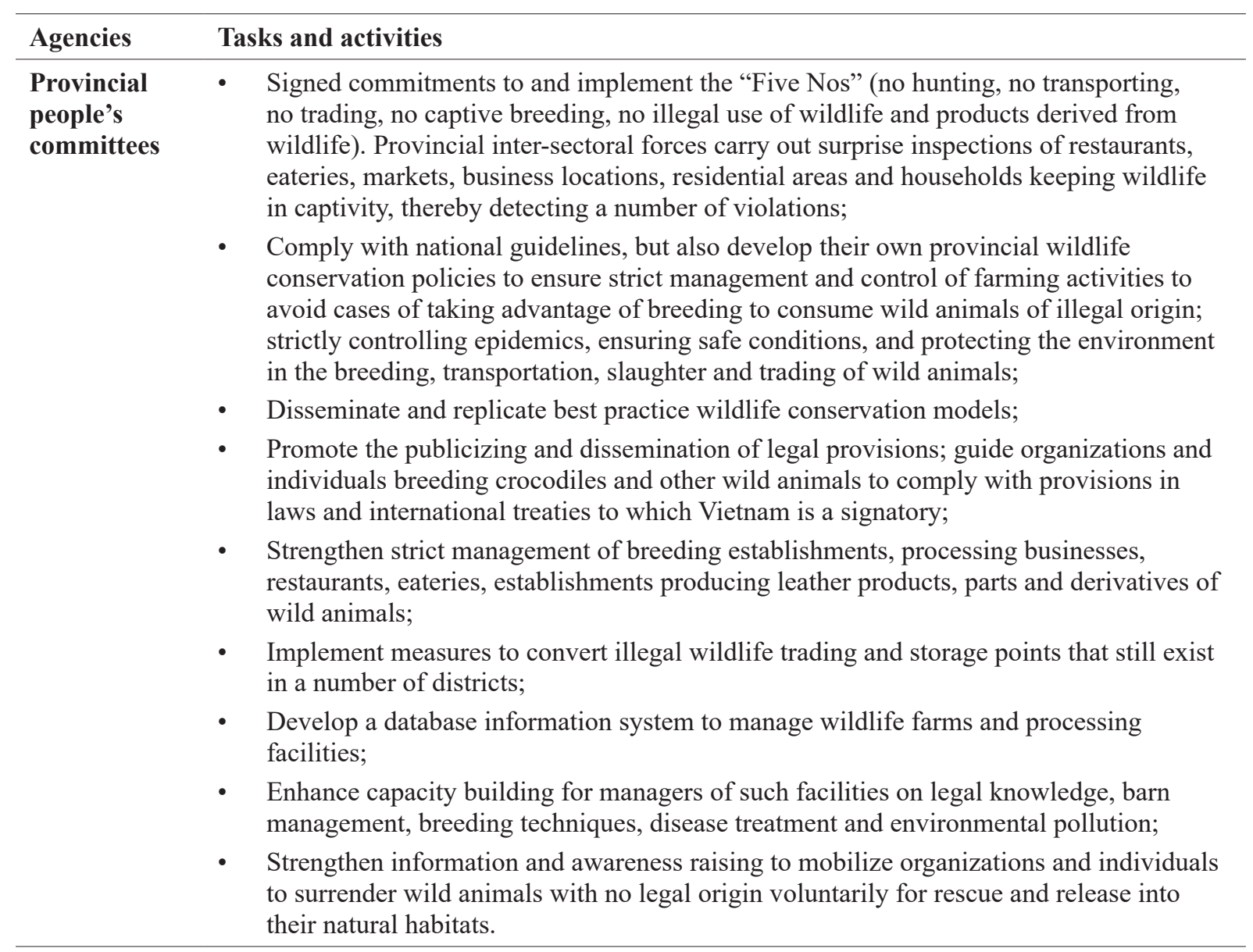

Sources: Centre for Environmental Information and Data (2020), Daklak Department of Justice (2020), Department of Forest Protection (2020), Phu (2020e), Tran (2020), Hoang (2021a), Manh (2021), Nguyen (2021a), Phan 2020)

International donors like the US and UK have announced significant financial commitments to developing, implementing and enforcing best practices and regulations to reduce the risk of pathogens spreading from wildlife and to strengthen mechanisms for monitoring, early warning, prevention and control of infectious diseases from animals (British Embassy Hanoi 2014; US Embassy and Consulate in Vietnam 2021). With this international support, many provinces have created positive change in conservation work with many nature reserves being established to protect and conserve rare animals such as elephants, gray-shanked douc langurs and saolas (Tran 2020).

\subsection{Effectiveness of policies and measures}

Our literature review and reflections from participants in the policy dialogue show regulations on wildlife in Vietnam being comprehensive and having gradually improved. Notable policies include Resolution No. 24-NQ/TW of Central Committee XI dated 3 June 2013 on proactively responding to climate change and strengthening natural resource management and environmental protection; Conclusion No. 56-KL/TW of the Politburo dated 23 August 2019 on continuing to implement the aforementioned resolution; Directive No. 29/CT-TTg of the Prime Minister dated 23 July 2020 on a number of urgent solutions for wildlife management; the Convention on International Trade in Endangered Species of Wild Fauna and Flora (CITES), the 2017 Law on Forestry, 2008 Law on Biodiversity (amended and supplemented in 2018); decrees on administrative sanctions for acts relating to the hunting, trapping, buying, selling, transporting and consumption of wildlife; and creating awareness and unity in society to participate in protecting endangered and rare wild animals and plants (Ly 2021). 
Vietnam has now issued some of Asia's most severe and widely applied sanctions against the wildlife trade. Nevertheless, implementation of these regulations is hampered by loopholes and contradictions in legislation. Meanwhile, overlapping duties between applicable ministries and agencies limit accountability in tackling the illegal wildlife trade. This is compounded by a lack of human resources, and physical and financial facilities. At the same time, inadequate awareness of the seriousness of wildlife crime, and a lack of training also limit the capacity of law enforcement agencies (Lang Son News 2020). As the previous section and Pham et al. (2021) have indicated, illegal wildlife trade and poaching have remained widespread in Vietnam since Covid-19. This is consistent with EIA data showing numbers of cases involving wildlife violations increasing, and almost doubling since 2019 (Figure 3).

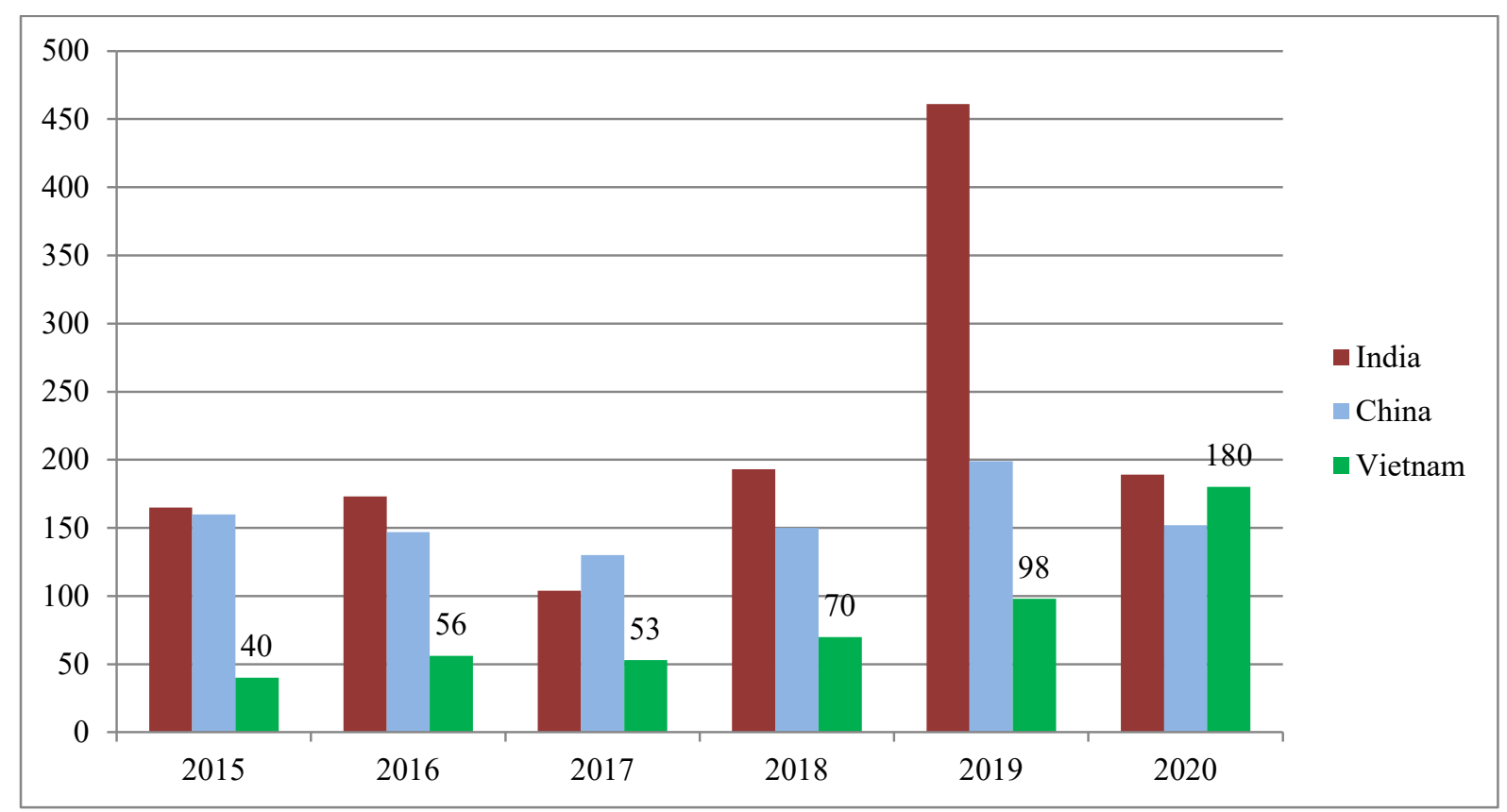

Figure 3. Numbers of cases involving wildlife violations in the top three illegal wildlife trade hotspots in Asia (EIA 2021)

Evidence to date shows illegal captive breeding, trading and consumption of wild animals still continuing in many provinces. This not only affects biodiversity conservation but can also affect people's health (Kien Giang Province Department of Natural Resources and Environment 2020). According to the Forest Protection Department (General Department of Forestry, Ministry of Agriculture and Rural Development), situations surrounding the hunting, trade, slaughter and consumption of wild animals remains complicated in many places. One ubiquitous problem is origin washing, where illegally-caught wild animals are mixed with those bred for trade and slaughter. If not strictly controlled, this will always pose a potential disease transmission risk for humans (Phan 2020). Provisions on animal rights are absent in legislation in Vietnam. Wildlife regulations are now scattered across specialized codes. In addition, under the 2015 Penal Code wildlife-related crimes are considered economic rather than an environmental offences. As such, the law ignores impacts on the environment and biodiversity, as well as on human health (Phan 2020).

While there is no clear evidence that pets and domestic animals can infect humans with SARS-CoV-2 or vice versa, biosecurity and hygiene measures are still needed to prevent infection (Bich 2021). From 2013-2019, the Vietnam Academy of Agriculture's Veterinary Biotechnology Key Laboratory worked with the Wildlife Conservation Society (WCS) and specialized units to actively monitor, sample and test thousands of animal samples in 70 sites in Vietnam. The team found six known types of coronavirus in wild or farm-grown wildlife including bats, field rats and porcupines (with a significantly increased positive rates in field rats) along the supply chain from merchants to markets 
to restaurants (Bich 2021). All farmers in Vietnam use antibiotics for livestock. When drug-resistant rats and bats come into contact with humans, people can become infected with these viruses through contact, through the air, or through consumption, with antibiotics being ineffective for treatment (BBC News 2021).

There is concern that despite illegal wildlife trading and poaching, local governments fail to address violations (Lang Son News 2020), and there is clear evidence of corrupt government officers being involved in illegal wildlife trade (H and Ngoc 2014) with a lack of transparency in the handling, preserving or destroying of confiscated wildlife products. In 2019, Vietnam did not appoint a CITES science agency, and as a consequence its capacity for surveillance and species identification in the large number of arrests in 2019 and early 2020 was limited (USAID Learns 2020). Agencies in Vietnam currently handle only small-scale violations, while the leaders of criminal organizations have yet to be punished to the fullest extent of the Penal Code, and major cases may not even be reported (USAID Learns 2020). Pham et al. (2021) also found that domestic poaching and wildlife trade remaining widespread during Covid-19, with the pandemic showing little effect in reducing crimes.

Another problem is the evident mismatch between trade data in Vietnam and importing countries. This poses additional challenges in monitoring actual numbers of wildlife being traded and giving a full understanding of the actual scale of the trade. One cause of disparities is the non-standard reporting of quantities and units by importers and exporters (e.g., importers report boxes, while exporters report kilograms of a traded animal product). This could be resolved with the standardization of reporting methods (units and quantities) and refined HS Codes that allow species-specific products to be recognized and reported.
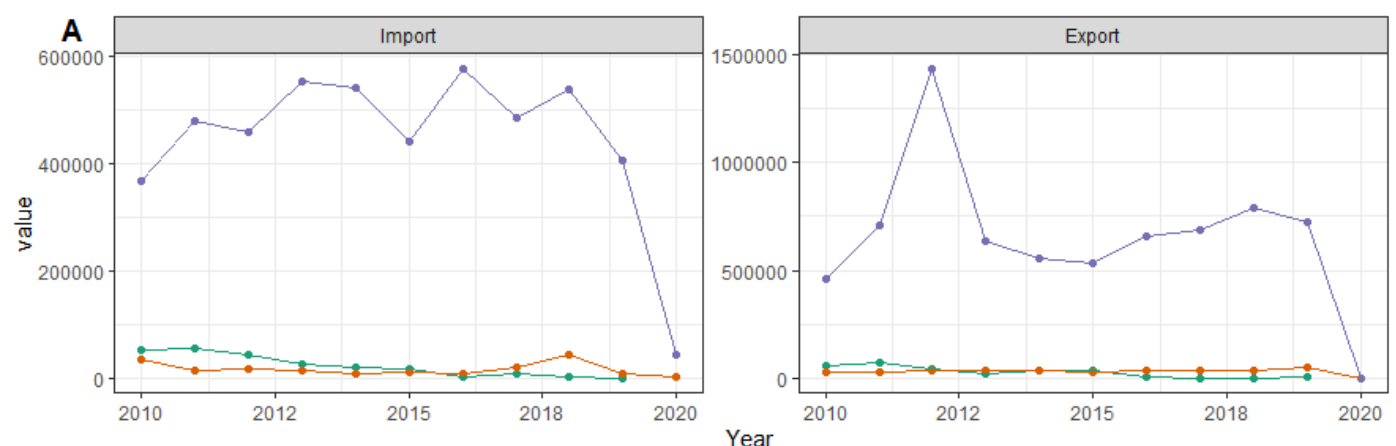

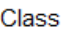

$\rightarrow$ Fish

$\rightarrow$ Mammals

$\rightarrow$ Reptiles
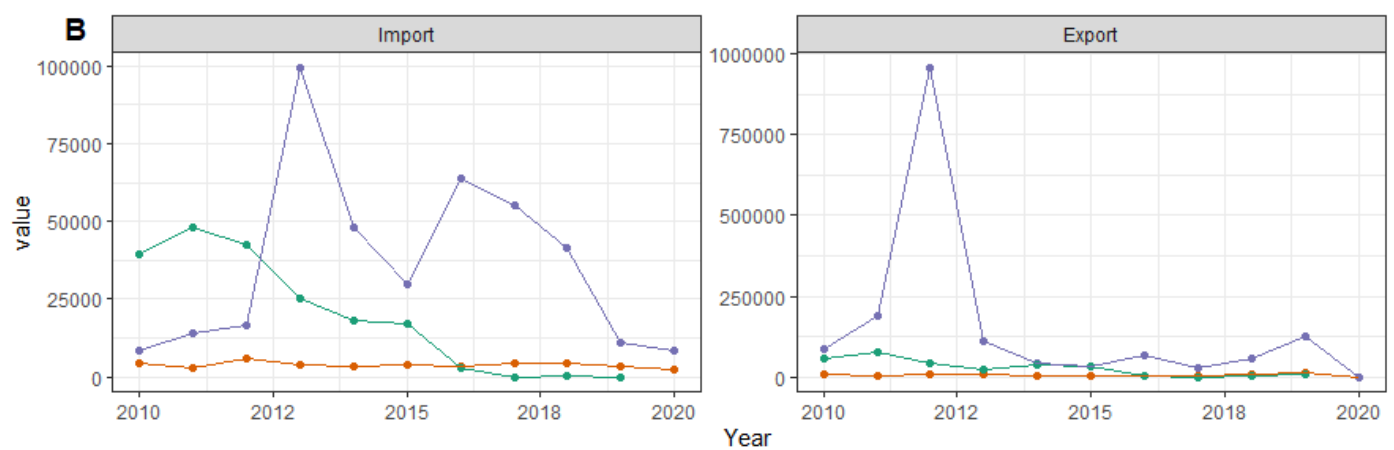

Class

- Fish

$\rightarrow$ Mammals

$\rightarrow$ Reptiles

Figure 4. A) CITES data on numbers of fish, mammal and reptile products reported by importers and Vietnam from 2010-2020; B) EIA data on fish, mammals and reptiles exported from Vietnam from 2010-2020 as reported by importers and Vietnam.

Sources: EIA (2021), CITES (2021) 


\section{Discussion and recommendations}

Covid-19 has impacted all aspects of conservation activities, disrupting wildlife protection funding and operations across the globe and in Vietnam. With all things considered, prevention is key to resources and cost-effective strategies for dealing with pandemics in the future. On a national and international scale, conservation actions and environmental law enforcement are the foundations for wildlife trade monitoring and early-response systems, and therefore among our greatest tools in monitoring zoonotic disease emergence and transfer from wildlife to humans. Our paper suggests several pathways, policies and measures to enhance the effectiveness of wildlife conservation policies in Vietnam.

\subsection{Holistic and cross-sectoral approaches for sustainable wildlife management}

Earlier sections have shown that overlapping mandates and weak collaboration amongst government agencies have hampered the effective implementation of wildlife conservation policies. Policy dialogue workshop participants highlighted the need for inter-ministerial policies to avoid confusion for local implementers. There should be a clearer assignment of functions and tasks on the management and protection of biodiversity, conservation of nature and wildlife between the two ministries involved to minimize overlap, and enhance the effectiveness of policy formulation and implementation and the efficient use of human resources and finances (Lang Son News 2020).

Researchers have conflicting views on imposing a complete ban on wildlife trade. On the one hand, some assert that wild meat consumption is mostly a luxury in Southeast Asia, and not a primary source of food security; when wild meat is no longer available local and impoverished people simply switch to other available meat sources such as fish and farmed livestock (Bennett 2002; Sandalj et al. 2016; Shreedhar and Mourato 2020; Ingram et al. 2021; Olmedo et al. 2021). On the other hand, an increasing number of studies have warned that in response to the pandemic, governments should not hasten policy decisions on banning wild meat trade and consumption due to nuanced concerns connecting wild meat with food and economic security (Tylianakis et al. 2021), particularly as Covid-19 has affected people's capacity to buy food to sustain their lives. Suggestions put forward to address this paradox include specifically targeted commercial wildlife trade bans on high-risk EID species, such as mammals and birds (Walzer 2020); increasing funding and shifting policy frameworks to enable immediate concurrent conservation actions that appropriately regulate nonsustenance wildlife products, increase habitat protection efforts to prevent wildlife acquisition, and substantially reduce human-wildlife interfaces (Borzée et al. 2020); or forming national or subnational regulations on a context-dependent basis to address more localized stakeholder needs and available biodiversity resources (Milder et al. 2012). Local people and multi-sectoral stakeholders who are dependent on wildlife trade for their livelihoods should also be party to any policy decisions on trade bans (Roe et al. 2020; Booth et al. 2021). Therefore, in order to make effective policy decisions for pandemic prevention in the context of EIDs, decision makers must find a trade-off between illegal and unsustainable commercialization of wildlife, and use of wildlife by impoverished communities for food security.

\subsection{Enhance wildlife trade monitoring}

For effective monitoring and elimination of illegal wildlife trade, the central government should tie successful wildlife conservation to provincial government performance criteria (Lang Son News 2020). Local leaders must bear the highest responsibility for cases involving illegal wildlife trade in their regions. 
As discussed earlier, monitoring illegal wildlife trade is challenging as crimes involve both online and offline activities. Research on various taxonomic groups have found that the wildlife trade market is significantly lacking in adequate international regulations and quickly becoming yet another driver of extinction (Siriwat and Nijman 2018; Marshall et al. 2020; Whitehead 2020). More alarmingly, market demand in cyber trade sectors was seemingly unaffected by the pandemic; the majority of monitored actors from one study did not seem to be phased by the connection between trade and the spreading of disease, and rarely added the issue as discourse in their sales discussions (Morcatty et al. 2021).

Feddema et al. (2021) found that group identity, decision making and group cohesion are prominent factors influencing wildlife trade. This means online wildlife trade participants can be monitored collectively as groups, and online demand reduction campaigns can be targeted at specific wildlife trading groups. Effective tools and guidelines for monitoring online wildlife trade legality have been developed by organizations like the Legal Atlas and the Global Initiative Against Transnational Organized Crime (Pascual and Wingard 2021). However, online trade monitoring by government and non-government conservation agencies may currently lack adequate coordination, and overlap in ways that prevent more effective expansion of online monitoring capabilities. International transboundary market demand for wildlife (both legal and illegal) is now driven and amplified largely by cyber trade sectors via social media platforms, e-commerce websites and the dark web (Roberts and HernandezCastro 2017; Xiao et al. 2017; Siriwat and Nijman 2018).

Since online trade is the greatest means of connection between wildlife sales and market demand on an international scale, international regulations must be considered and enacted through international treaties, agreements or declarations. Online trade standards should be fluid and standardized to allow for more effective monitoring and regulation of the global wildlife market. While hierarchical classification systems such as that of the Convention on International Trade in Endangered Species (CITES) provide a standard format for regulatory bodies to follow, Vietnam may want to increase trade protections of specific species due to their potential for local extinction. Therefore, CITES should be updated to reflect both national and international species trade policy updates, and nations should be responsible for submitting updates accordingly. Furthermore, as recommended by Andersson et al. (2021), modified HS codes would be a viable way to create specificity in internationally traded wildlife goods in a way that can be analysed and directly connected to specific species, especially those likely to be traded for traditional Chinese medicine (TCM), pets and wild meat. International interagency partnerships should be formed, and monitoring activities allocated productively to ensure systematic monitoring of online wildlife trade across websites and the dark web. Furthermore, participating organizations should continue online monitoring activities in ways that are somewhat clandestine to the public, because wide publication of monitoring activities, especially for the purpose of enforcing trade regulations, increases the likelihood of trade going "underground" through channels that are difficult or impossible to research and regulate.

Pham et al. (2021) highlighted the need to employ mixed policy instruments including: strengthening partnerships with neighbouring countries in dealing with transboundary wildlife crime; improving the capacity of monitoring and evaluation systems; increasing the powers and capacity of rangers (e.g., species identification) so they can become more effective in controlling wildlife violations both inside and outside forests; increasing fines and punishment for wildlife crimes, and considering them serious crimes; and finding a more appropriate punishment system rather than the current administrative and penal approach for poor communities where people have no money. 


\subsection{Diversify funding sources for both state and non-state actors}

Past pandemic (Swift et al. 2007) and Covid-19 have caused national economies to lose billions of dollars and significantly reduced funding for conservation (Fukushima et al. 2020). Zoos contribute to conservation action primarily through wildlife education, conservation project donations and ex-situ conservation breeding/ supplementation (Tribe and Booth 2003; Zimmerman 2010; Conde et al. 2011). However, drastic reductions in earnings during Covid-19 for zoos and conservation centres, which operate almost exclusively from public ticket purchases, has curbed outgoing conservation donations and supplies for in-situ conservation programmes, and put their captive animals at risk.

Current global climate change efforts prioritize emissions reductions, while countries are developing post-Covid 19 strategies to boost economic growth. These recovery plans will not be "green" or sustainable for wildlife management unless adequate financial resources are made available to protect and conserve wildlife (Helm 2020; Monbiot 2020; Sandbrook et al. 2020). With global commitment to providing sufficient finance for wildlife conservation, Vietnam needs to develop and diversify conservation funding strategies. Vietnam, like many other countries in world, currently has six main funding sources for conservation, each with its own opportunities and challenges (Table 2).

Table 2. Funding sources for wildlife conservation in Vietnam

\begin{tabular}{|c|c|c|c|}
\hline Funding source & Opportunities & Challenges & $\begin{array}{l}\text { Recommendations to } \\
\text { address funding gaps }\end{array}$ \\
\hline \multirow[t]{3}{*}{$\begin{array}{l}\text { 1. State } \\
\text { budget }\end{array}$} & $\begin{array}{l}\text { The government } \\
\text { commits to provide } \\
\text { annual and long- } \\
\text { term funding for the } \\
\text { management of special } \\
\text { use and protection } \\
\text { forests }\end{array}$ & $\begin{array}{l}\text { State funding for the forestry } \\
\text { sector can only partly meet } \\
\text { actual needs. This might cause } \\
\text { vulnerabilities for the job } \\
\text { security of park staff } \\
\text { The majority of state } \\
\text { funding is channelled to } \\
\text { forest plantation, staff } \\
\text { and infrastructure, while } \\
\text { biodiversity conservation } \\
\text { and wildlife conservation are } \\
\text { underfunded }\end{array}$ & $\begin{array}{l}\text { Provide adequate funding } \\
\text { for wildlife conservation, } \\
\text { including the National } \\
\text { Biodiversity Strategy } 2021 \text { - } \\
2040 \text { and vision to } 2050, \\
\text { and Vietnam Forestry } \\
\text { Development Strategy } 2021 \text { - } \\
2030 \text { with vision to } 2050 \\
\text { Create a post-Covid economic } \\
\text { package to help move the } \\
\text { recovery economy towards a } \\
\text { more sustainable future }\end{array}$ \\
\hline & & $\begin{array}{l}\text { State funding for biodiversity } \\
\text { conservation is used } \\
\text { inefficiently due to weak } \\
\text { collaboration between actors }\end{array}$ & $\begin{array}{l}\text { Increase salaries and payment } \\
\text { for governmental officials who } \\
\text { work on wildlife protection, } \\
\text { increase incentives, } \\
\text { appropriate levels of support } \\
\text { and inspiration to rangers } \\
\text { and anti-poaching members } \\
\text { to increase motivation and } \\
\text { commitment to wildlife } \\
\text { protection }\end{array}$ \\
\hline & & & $\begin{array}{l}\text { Policy and enforcement must } \\
\text { remain vigilant, and resources } \\
\text { allocated to enforcers when } \\
\text { borders fully reopen to } \\
\text { prevent business-as-usual } \\
\text { wildlife trade }\end{array}$ \\
\hline
\end{tabular}


Table 2: Continue

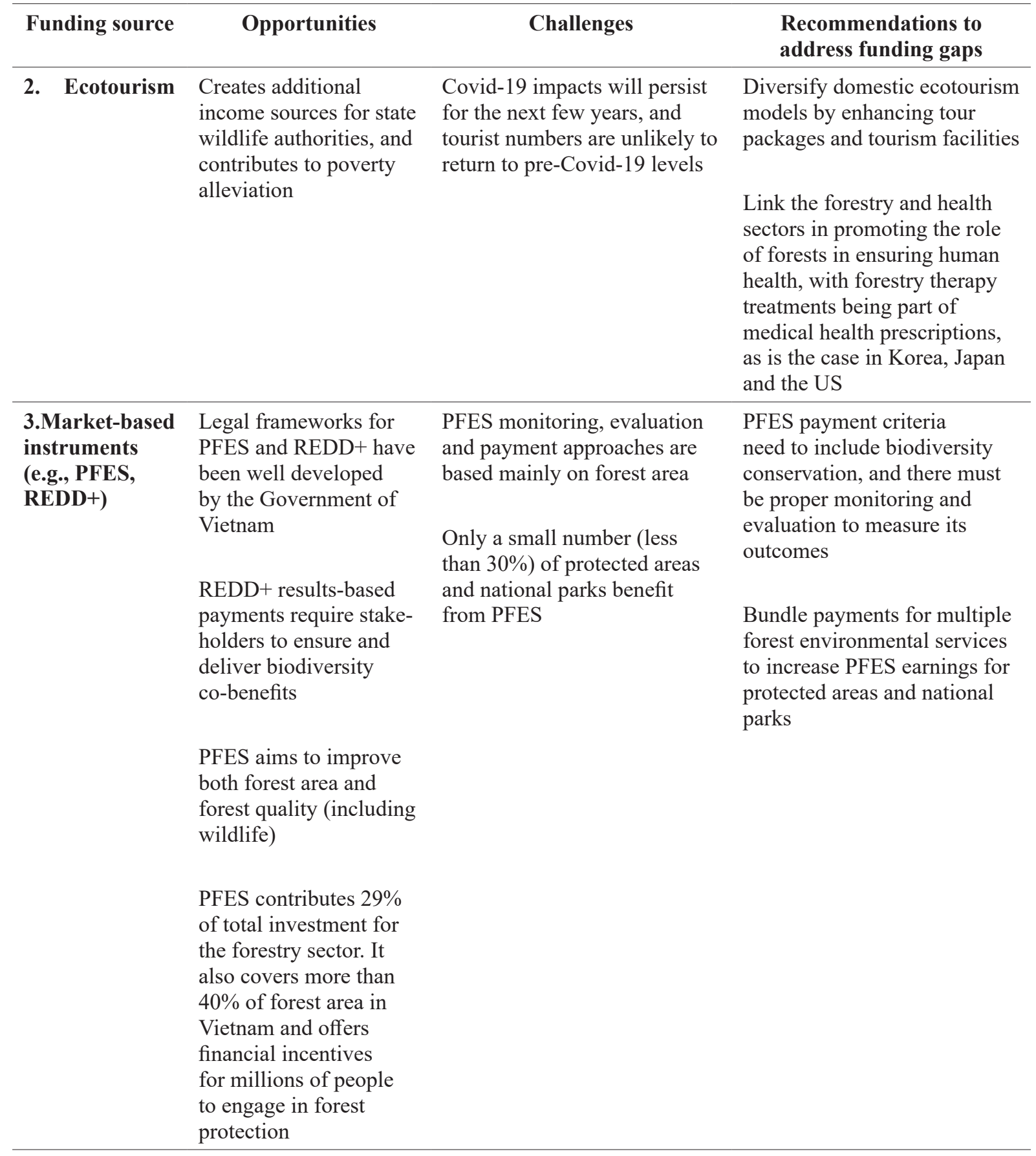


Table 2: Continue

\begin{tabular}{|c|c|c|c|}
\hline Funding source & Opportunities & Challenges & $\begin{array}{l}\text { Recommendations to } \\
\text { address funding gaps }\end{array}$ \\
\hline \multirow[t]{3}{*}{$\begin{array}{l}\text { 4.International } \\
\text { funding }\end{array}$} & \multirow[t]{3}{*}{$\begin{array}{l}\text { Many protected areas } \\
\text { and national parks } \\
\text { are heavily funded } \\
\text { by international } \\
\text { organizations }\end{array}$} & $\begin{array}{l}\text { Conservation funding is } \\
\text { expected to decrease with } \\
\text { post-pandemic economic } \\
\text { recovery programmes to } \\
\text { support local livelihoods } \\
\text { in coming years. This } \\
\text { will restrict the ability of } \\
\text { conservation implementers to } \\
\text { manage PAs effectively, force } \\
\text { key staff layoffs, and prevent } \\
\text { purchases of critical devices } \\
\text { and equipment }\end{array}$ & \multirow[t]{3}{*}{$\begin{array}{l}\text { Establish and develop } \\
\text { a national conservation } \\
\text { emergency fund to support } \\
\text { NGOs, wildlife protection } \\
\text { authorities, and communities } \\
\text { to deal with crises }\end{array}$} \\
\hline & & $\begin{array}{l}\text { Limited opportunities for } \\
\text { conservationists to undertake } \\
\text { their work, e.g., disrupted } \\
\text { supplies for field rangers, and } \\
\text { community outreach work }\end{array}$ & \\
\hline & & $\begin{array}{l}\text { Funding only available during } \\
\text { certain periods and therefore } \\
\text { not permanent }\end{array}$ & \\
\hline \multirow[t]{2}{*}{ 5.Private sector } & \multirow[t]{2}{*}{$\begin{array}{l}\text { Most international } \\
\text { and national firms } \\
\text { have committed to } \\
\text { sustainable development } \\
\text { plans, including wildlife } \\
\text { conservation }\end{array}$} & $\begin{array}{l}\text { There is no monitoring and } \\
\text { evaluation to monitor private } \\
\text { sector responsibilities in } \\
\text { complying with environmental } \\
\text { protection policies }\end{array}$ & $\begin{array}{l}\text { Develop a financial system } \\
\text { that encourages local and } \\
\text { national enterprises to invest } \\
\text { in conservation and nature } \\
\text { protection. Through a tax } \\
\text { system, increase the share } \\
\text { of national to international } \\
\text { funding }\end{array}$ \\
\hline & & & $\begin{array}{l}\text { Strengthen monitoring } \\
\text { and evaluation to monitor } \\
\text { financial flows and finance } \\
\text { committed to and disbursed } \\
\text { for biodiversity conservation }\end{array}$ \\
\hline $\begin{array}{l}\text { 6.Public } \\
\text { self-formed } \\
\text { conservation } \\
\text { trust funds }\end{array}$ & $\begin{array}{l}\text { A large number of trusts } \\
\text { with funds raised by } \\
\text { different social groups } \\
\text { have been established in } \\
\text { recent years }\end{array}$ & $\begin{array}{l}\text { These funds lack the technical } \\
\text { capacity to channel funding } \\
\text { to the right place, the right } \\
\text { species and the right target } \\
\text { group at the right time }\end{array}$ & $\begin{array}{l}\text { Capacity building is } \\
\text { required, and monitoring } \\
\text { and evaluation are necessary } \\
\text { to ensure the transparency } \\
\text { and accountability of these } \\
\text { schemes }\end{array}$ \\
\hline
\end{tabular}

Sources: Stone and Nyaupane (2017), Lindsey et al. (2018), Pham et al. (2018), Lindsey et al. (2020), McCleery et al. (2020), Pham et al. (2020), Spenceley et al. (2020), Smith et al. (2021), authors own analysis (2021), Nguyen (2021c) 


\subsection{Post- Covid-19 recovery plans and preventive measures to reduce the risk of future disease outbreaks}

Most recovery plans have focused mostly on human-centric factors that relate to socioeconomic actions, while also accounting for public health with protective vaccinations. Even with restrictions and vaccinations, the probability of wildlife or domestic animal reservoirs of Covid-19 (and other EIDs) is still to be determined. However, this does pose a significant risk to recovery plans if the virus begins to mutate in animal hosts in ways that resist vaccine protections, as has been seen with mutations in human hosts over the duration of the pandemic. The World Health Organization (WHO) and other health-based institutions are adopting the "One Health" approach, which is a framework designed to implement policies, regulations, and research that aim to improve our understanding of the human-animal interface and implement surveillance, prevention and mitigation protocols thereafter (Mackenzie and Jeggo 2019). Since the One Health approach highlights the need for wildlife monitoring and the understanding of human-animal interfaces, it is recommended that transboundary partnerships be established, especially in tropical and neotropical nations, to adopt the One Health framework, and for funding agencies to support research and advocacy efforts to monitor humananimal interactions and EIDs.

Due to lockdowns and restrictions on social interaction, a global increase has been recorded in people keeping animals as companions and to relieve stress (BBC News 2021). Conservationists and epidemiologists have warned that wildlife farming is putting humans at risk of infection from deadly viruses (BBC News 2021). To prevent future pandemics, large-scale virus screening for land and marine wildlife, especially exposed species, is needed to develop more rigorous prevention strategies (Hoang 2021b). It is also important to establish strategic disease risk control measures and regulations (Ten et al. 2021), and take more drastic measures, such as establishing wildlife sanctuaries in place of zoos, and incrementally closing off sanctuaries over time to maximize conservation value (Pepper and Voigt 2021). It is necessary to consult with experts in relevant fields, including scientists specializing in the study of viruses, epidemiologists, trade experts, law enforcement authorities and agriculture experts, before issuing or applying any new regulations (TRAFFIC 2020).

As diseases are often associated with poor conditions in wildlife farms, the authorities should reassess the policy of allowing wildlife breeding, and review actual implementation to ensure such facilities comply with requirements. In particular, it is necessary to close and take strict measures in handling establishments that take advantage of this policy to participate in markets for illegal wildlife trade and consumption (Lang Son News 2020). At the same time, further research is needed to understand whether and how different animals can be affected by Covid-19 (Center for Disease Control and Prevention 2021).

Unprecedented changes to the movement and behavioural patterns of wildlife are of significant interest to ecologists and conservationists alike; however, studying these changes is challenging without resources, funding, and the ability to monitor them. These issues greatly outline the need to put remote systems in place that will allow conservationists to continue monitoring biodiversity, even in the case of largescale lockdowns and restrictions. Moreover, strengthening environmental protection campaigns and environmental education will help wake people up to the dangers of consuming and using wild animals, and contribute to condemnation and boycotts for changing such behaviour (Ly 2021).

To develop post-Covid-19 recovery strategies and prevent future pandemics, research is required to address current knowledge gaps on species distribution, habitats and population sizes. It is also necessary to ascertain levels of dependency on wildlife among local people and Vietnam's economy to ensure better policies on harvesting, farming, trading and consumption of wildlife. Law enforcement should prioritize and focus on illegal wildlife trade 'hotspots'. Things to consider are the impacts of wildlife farming, the effectiveness of SMART patrol models in in-situ wildlife conservation, controlling wildlife trade activities from source (hunting), and the effectiveness of policies and financial instruments in biodiversity outcomes. 


\section{References}

Andersson AA, Tilley HB, Lau W, Dudgeon D, Bonebrake TC and Dingle C. 2021. CITES and beyond: Illuminating 20 years of global, legal wildlife trade. Global Ecology and Conservation vol. 26: e01455.

Anh N. 22 September 2021. Wildlife trade returns as pandemic restrictions are eased. Nhan Dan Online. 22 September. Accessed 10 November 2021. https://nhandan.vn/moi-truong/nan-buonban-dong-vat-hoang-da-dang-quay-tro-lai-khi-han-che-ve-dai-dich-duoc-noi-long-666062/.

Basu S, Jabin G, Ghosh A, Singh SK, Mitra A, Chandra K and Thakur M. 2020. Ascertaining suspected wildlife trade from detained parcels under international shipment. In Proceedings of the Zoological Society Vol. 73, No. 3. India: Springer. pp. 320-323.

Batiran K and Fisher MR. 2020. From hunter to protector: The invention and reinvention of the Nuri Talaud. Forest and Society. pp. 35-47.

BBC News. 2021. Increased risk of spreading deadly viruses from pets that are wild animals. Accessed 10 November 2021. https://www.bbc.com/vietnamese/vietnam-58689170.amp.

Bennet EL. 2002. Is there a link between wild meat and food security? Conservation Biology 16(3): 590-592.

Bich T. 2021. Prevention of Covid-19 disease when in contact with pets. Hanoi Department of Health. Accessed 10 November 2021. https://soyte.hanoi.gov.vn/phong-chong-dich-benh/-/ asset_publisher/4IVkx5Jltnbg/content/phong-benh-covid-19-khi-tiep-xuc-voi-vat-Nuoi? 101 INSTANCE_4IVkx5Jltnbg_viewMode=view.

Binh N. 8 November 2021. Nghi Loc Police: Arrested 2 cases of transporting 3 rare pangolins. Television and Radio Company of Nghe An. Accessed 10 November 2021. https:// truyenhinhnghean.vn/phap-luat/202111/cong-an-nghi-loc-bat-giu-2-vu-van-chuyen-3-ca-the-te-tequy-hiem-53d0ee6/.

Blair ME, Le MD, Sethi G, Thach HM, Nguyen VT, Amato G ... and Sterling EJ. 2017. The importance of an interdisciplinary research approach to inform wildlife trade management in Southeast Asia. BioScience 67(11): 995-1003.

Booth H, Arias M, Brittain S, Challender DW, Khanyari M, Kuiper T ... and Milner-Gulland EJ. 2021. Saving lives, protecting livelihoods, and safeguarding nature: Risk-based wildlife trade policy for sustainable development outcomes post-Covid-10. Frontiers in Ecology and Evolution 9(99).

Borzée A, McNeely J, Magellan K, Miller JR, Porter L, Dutta T ... and Zhang L. 2020. Covid-19 highlights the need for more effective wildlife trade legislation. Trends in Ecology \& Evolution.

Can ÖE, D'Cruze N and Macdonald DW. 2019. Dealing in deadly pathogens: Taking stock of the legal trade in live wildlife and potential risks to human health. Global Ecol Conserv 17: e00515.

Carrillo-Páez CC. 2018. Wildlife trafficking by parcel service: A national problem that threatens biodiversity. In Green Crime in Mexico. Cham: Palgrave Macmillan. pp. 115-125.

Centre for Environmental Information and Data. 2020. Prevention of Covid-19: Strict control of transportation and use of wild animals. CEID. Accessed 10 November 2021. http://ceid.gov.vn/ phong-chong-dich-covid-19-kiem-soat-chat-che-van-chuyen-su-dung-dong-vat-hoang-da/.

Chakraborty I and Maity P. 2020. Covid-19 outbreak: Migration, effects on society, global environment and prevention. Science of the Total Environment 728: 138882.

Conde DA, Flesness N, Colchero F, Jones OR and Scheuerlein A. 2011. An emerging role of zoos to conserve biodiversity. Science 331(6023): pp. 1390-1391.

Corlett RT, Primack RB, Devictor V, Maas B, Goswami VR, Bates AE ... and Roth R. 2020. Impacts of the coronavirus pandemic on biodiversity conservation. Biological conservation 246: 108571.

DH. 2018. Selling wild game meat via Facebook, fined VND 6 million. Tuoitre Online. Accessed 10 November 2021. https://tuoitre.vn/ban-thit-thu-rung-qua-facebook-bi-phat-6-trieu-dong-2018111 6132303948.htm. 
Di Minin E, Leader-Williams N and Bradshaw CJ. 2016. Banning trophy hunting will exacerbate biodiversity loss. Trends in Ecology \& Evolution 31(2): pp. 99-102.

Doan H. 12 October 2021. Nghe An will hand over 9 tigers seized from people's homes to 2 provinces. TuoiTre Online. Accessed 10 November 2021. https:/tuoitre.vn/nghe-an-se-ban-giao-9-con-hothu-giu-tu-nha-dan-cho-2-tinh-20211012152042117.htm.

Driessen MM. 2021. Covid-19 restrictions provide a brief respite from the wildlife roadkill toll. Biological conservation 256: 109012.

Duc H. 10 September 2021. Catching 'loggers' keeping the carcasses of wild animals in 3 freezers. Tuoitre Online. Accessed 10 November 2021. https://tuoitre.vn/bat-lam-tac-chat-kin-xac-thurung-trong-3-tu-cap-dong-20210910101647748.htm.

DW. 2020. Coronavirus: South Asia sees rise in poaching during lockdowns. Accessed 1 November 2021. https://www.dw.com/en/coronavirus-south-asia-sees-rise-in-poaching-duringlockdowns/a-54090081.

ENV. 2020. Law enforcement responsiveness report 2020. Education. Education for Nature Vietnam. https://env4wildlife.org/wp-content/uploads/2021/09/ Responsiveness-Report-EN-Sept-20-2021Final-low-resolution.pdf

ENV. 2021. Wildlife crime bulletin. Education for Nature Vietnam. 1:2021. Wildlife crime bulletin. Accessed 10 November 2021. https://env4wildlife.org/wp-content/uploads/2021/08/WildlifeCrime-Bulletin-01.2021-August-31-2021-Website.pdf.

Feddema K, Harrigan P, Nekaris KAI and Maghrifani D. 2020. Consumer engagement behaviors in the online wildlife trade: Implications for conservationists. Psychology \& Marketing 37(12): $1755-1770$.

Fukushima CS, Mammola S and Cardoso P. 2020. Global wildlife trade permeates the Tree of Life. Biological Conservation 247: 108503.

Ghosal A and Casey M. 2020. Coronavirus lockdowns increase poaching in Asia, Africa. AP News. Accessed 1 November 2021. https://apnews.com/article/india-ap-top-news-international-newsasia-virus-outbreak-9df0cc21045578ad86696bc05721c706

Gibson CC and Marks SA. 1995. Transforming rural hunters into conservationists: An assessment of community-based wildlife management programs in Africa. World Development 23(6): 941-957.

Ha M and Ngoc H. 2014. Discipline 2 officials, forest rangers aiding in the sale and purchase of wild animals. TuoiTre Online. Accessed 10 November 2021. https://tuoitre.vn/ky-luat-2-can-bo-tieptay-mua-ban-thu-rung-659458.htm.

Ha A. 2020. Lam Dong: Detected 2 households keeping in captivity and freezing a large number of rare and precious wild animals. Ho Chi Minh City Police Newspaper. Accessed 10 November 2021. https://congan.com.vn/doi-song/lam-dong-phat-hien-2-o-nuoi-nhot-cap-dong-dong-vat-quyhiem_99547.html.

Hai D. 2018. Breaking the wildlife trade project. Ho Chi Minh City Police Newspaper. Accessed 10 November 2021. https://congan.com.vn/an-ninh-kinh-te/pha-thanh-cong-chuyen-an-buon-dongvat-hoang-da-trai-phep_55426.html.

Harrison RD, Sreekar R, Brodie JF, Brook S, Luskin M, O'Kelly H ... and Velho N. 2016. Impacts of hunting on tropical forests in Southeast Asia. Conservation Biology 30(5): pp. 972-981.

Helm D. 2020. The environmental impacts of the coronavirus. Environmental and Resource Economics 76(1): pp. 21-38.

Hoang N. 2021a. Signing of One Health Partnership Framework to prevent zoonotic diseases. Natural Resources \& Environment Newspaper. Accessed 10 November 2021. https:// baotainguyenmoitruong.vn/ky-ket-khung-doi-tac-mot-suc-khoe-phong-chong-dich-benh-tu-dongvat-sang-nguoi-321888.html.

Hoang T. 2021b. Experts call for wildlife screening to prevent SARS-CoV-2 from mutating. Newspaper - VNA. Accessed 10 November 2021. https://baotintuc.vn/the-gioi/gioi-chuyen-giakeu-goi-ra-soat-dong-vat-hoang-da-de-ngan-sarscov2-sinh-bien-the-20211004065143390.htm.

Hoang V. 2021c. Hanoi Wildlife Rescue Center: Improving the quality of rescue work. New Hanoi Newspaper. Accessed 10 November 2021. http:/hanoimoi.com.vn/tin-tuc/Nong-nghiep/1006665/ trung-tam-cuu-ho-dong-vat-hoang-da-ha-noi-nang-cao-chat-luong-cong-tac-cuu-ho. 
Hobbs EC and Reid TJ. 2021. Animals and SARS-CoV-2: Species susceptibility and viral transmission in experimental and natural conditions, and the potential implications for community transmission. Transboundary and Emerging Diseases 68(4): pp. 1850-1867.

Hockings M, Dudley N, Ellio W, Ferreira MN, MacKinnon K, Pasha M, Yang A. 2020. Editorial essay: Covid-19 and protected and conserved areas. PARKS. 2020. 26: 7-24. doi: 10.2305/IUCN. CH. 2020. PARKS-26-1MH.

Hong T. 2018. Arresting people who bring rare wild animals to sell. Ho Chi Minh City Police Newspaper. Accessed 10 November 2021. https://congan.com.vn/vu-an/bat-doi-tuong-mangdong-vat-hoang-da-quy-hiem-di-ban_49870.html.

Hu B, Zeng LP, Yang XL, Ge XY, Zhang W, Li B ... and Shi ZL. 2017. Discovery of a rich gene pool of bat SARS-related coronaviruses provides new insights into the origin of SARS coronavirus. PLoS pathogens 13(11): e1006698.

Ingram DJ, Coad L, Milner-Gulland EJ, Parry L, Wilkie D, Bakarr MI ... and Abernethy K. 2021. Wild meat is still on the menu: Progress in wild meat research, policy, and practice from 2002 to 2020. Annual Review of Environment and Resources 46.

Jayaram BK, Leke A, Ooko-ombaka A and Sun YS. 2020. Tackling Covid-19 in Africa: An unfolding health and economic crisis that demands bold action. McKinsey \& Company.

Jones KE, Patel NG, Levy MA, Storeygard A, Balk D, Gittleman JL, Daszak P. 2008. Global trends in emerging infectious diseases. Nature 451(7181): 990-993.

Kumar V, Pruthvishree B, Pande T, Sinha D, Singh B, Dhama K and Malik YS. 2020. SARS-CoV-2 (Covid-19): Zoonotic origin and susceptibility of domestic and wild animals. J Pure Appl Microbiol 14(1): pp. 741-747.

Le M. 2021. Prevent poaching to ensure peace for the flock of birds in the migratory season. Tuoitre Online. Accessed 10 November 2021. https://tuoitre.vn/ngan-chan-nan-san-bat-tra-lai-binh-yencho-dan-chim-troi-mua-di-cu-20210916092847715.htm.

Leroy EM, Gouilh MA and Brugère-Picoux J. 2020. The risk of SARS-CoV-2 transmission to pets and other wild and domestic animals strongly mandates a one-health strategy to control the Covid-19 pandemic. One Health 10.

Lin J. 2005. Tackling Southeast Asia's illegal wildlife trade. Sybil 9(191).

Lindsey P, Allan J, Brehony P, Dickman A, Robson A, Begg C, Tyrrell P. 2020, 'Conserving Africa's wildlife and wildlands through the Covid-19 crisis and beyond', Nature Ecology \& Evolution, vol. 4, no. 10, pp. 1300-1310.

Lindsey PA, Miller JR, Petracca LS, Coad L, Dickman AJ, Fitzgerald KH, Hunter LT. 2018. More than $\$ 1$ billion needed annually to secure Africa's protected areas with lions. Proceedings of the National Academy of Sciences 115(45): E10788-E10796.

Lindsey PA, Roulet PA and Romanach SS. 2007. Economic and conservation significance of the trophy hunting industry in sub-Saharan Africa. Biological Conservation 134(4): pp. 455-469.

Liu Z, Ciais P, Deng Z, Lei R, Davis SJ, Feng S, Schellnhuber HJ. 2020. Near-real-time monitoring of global CO2 emissions reveals the effects of the Covid-19 pandemic. Nature communications 11(1): 1-12.

Loeb J. 2021. Zoos struggling to access Covid-19 support. The Veterinary Record 188(7): p. 242.

Luo RF, Liu CF, Gao JJ, Wang TY, Zhi HY, Shi PF and Huang JK. 2020. Impacts of the Covid-19 pandemic on rural poverty and policy responses in China. Journal of Integrative Agriculture 19(12): pp. 2946-2964.

Ly T. 2021. Strengthen management and enforcement of wildlife protection laws. Public Security News. Accessed 10 November 2021. https://cand.com.vn/van-de-hom-nay-thoi-su/tang-cuongquan-ly-thuc-thi-phap-luat-bao-ve-dong-vat-hoang-da-i633483/.

Mackenzie JS and Jeggo M. 2019. The One Health approach-Why is it so important? Tropical Medicine \& Infectious Diseases 4(2): pp. 88.

Manh D. 2021. Potential disease risk from hunting wild animals. Ho Chi Minh City Police Newspaper. Accessed 10 November 2021. https://congan.com.vn/an-ninh-kinh-te/tiem-an-nguy-co-dich-benhtu-san-bat-dong-vat-hoang-da_111704.html. 
Maron DF. 2020. Pandemic-induced poaching surges in Uganda. National Geographic. Accessed 1 November 2021. https://www.nationalgeographic.com/animals/article/covid19-behind-ugandapoaching

Marshall BM, Strine C and Hughes AC. 2020. Thousands of reptile species threatened by underregulated global trade. Nature Communications 11(1): pp. 1-12.

McCleery RA, Fletcher Jr RJ, Kruger LM, Govender D and Ferreira SM. 2020. Conservation needs a Covid-19 bailout. Science 369(6503): 515-516.

McNamara T, Richt JA and Glickman L. 2020. A critical needs assessment for research in companion animals and livestock following the pandemic of Covid-19 in humans. Vector-Borne and Zoonotic Diseases 20(6): pp. 393-405.

Md-Zain B, Mohd-Ridwan A, Muhdsahimi H, Abdul-Latiff M and Chan E. 2020. Mixed-species association among Malaysian primates during the Covid-19 outbreak in genting highlands, Peninsular Malaysia. Journal of Sustainability Science and Management 16(1): pp.1-10.

Melin AD, Janiak MC, Marrone F, Arora PS and Higham JP. 2020. Comparative ACE2 variation and primate Covid-19 risk. Communications Biology 3(1): pp. 1-9.

Milder JC, Buck LE, DeClerck F and Scherr SJ. 2012. Landscape approaches to achieving food production, natural resource conservation, and the millennium development goals. In Integrating ecology and poverty reduction. New York, NY: Springer. pp. 77-108.

Monbiot G. 2020. Airlines and oil giants are on the brink. No government should offer them a lifeline. The Guardian.

Morcatty TQ, Feddema K, Nekaris KAI and Nijman V. 2021. Online trade in wildlife and the lack of response to Covid-19. Environmental Research 193: 110439.

Ngoc H. 2020. Blocking and arresting cars carrying wild animals from public news. Ho Chi Minh City Police Newspaper. Accessed 10 November 2021. https://congan.com.vn/an-ninh-kinh-te/lamdong-chan-bat-xe-khach-16-cho-cho-dong-vat-hoang-da_100938.html.

Nguyen H. 2020a. Wild animal hunting videos are rampant online. Vietnam Agriculture Newspaper. Accessed 10 November 2021. https://nongnghiep.vn/tran-lan-video-san-bat-dong-vat-hoang-datren-mang-d260185.html.

Nguyen H. 2021a. The Ministry of Health has certified that the Department of Animal Health is capable of testing for SARS-CoV-2. Department of Animal Health. Accessed 10 November 2021. http://www.cucthuy.gov.vn/Pages/bo-y-te.aspx.

Nguyen T. 2020b. Corona Virus - From the field to the table: Research results show that the supply chain of wild animals for food has increased the risk of transmission of Corona virus to humans. Press release. Wildlife Conservation Society. Accessed 10 November 2021. https://programs. wcs.org/vietnam/vi-vn/News/Media-Releases-VN/ID/14333/Vi-rut-Corona--Tu-thuc-ia-en-banan-Ket-qua-nghien-cuu-cho-thay-chuoi-cung-ung-ong-vat-hoang-da-lam-thuc-pham-a-gia-tangnguy-co-lay-truyen-vi-rut-Corona-sang-con-nguoi.aspx.

Nhat H. 2018. Large-scale hunting of wild animals in Lam Dong: Prosecution of the case. Tuoitre Online. Accessed 10 November 2021. https://tuoitre.vn/vu-san-ban-thu-rung-quy-mo-lon-o-lamdong-khoi-to-vu-an-244039.htm.

Nijman V. 2010. An overview of international wildlife trade from Southeast Asia. Biodiversity and Conservation 19(4): pp. 1101-1114.

Olmedo A, Veríssimo D, Challender DW, Dao HTT and Milner-Gulland EJ. 2021. Who eats wild meat? Profiling consumers in Ho Chi Minh City, Vietnam. People and Nature 3(3): 700-710.

PanNature. 2021. Wildlife smuggling in Vietnam is still very "busy". PanNature. Accessed 10 November 2021. https://nature.org.vn/vn/2021/06/buon-lau-dong-vat-hoang-da-tai-viet-nam-vandien-ra-rat-soi-dong/.

Pascual M and Wingard J. 2021. Assessing online wildlife marketing.

Patel NG, Rorres C, Joly DO, Brownstein JS, Boston R, Levy MZ and Smith G. 2015. Quantitative methods of identifying the key nodes in the illegal wildlife trade network. Proceedings of the National Academy of Sciences 112(26): pp. 7948-7953.

Pepper A and Voigt K. 2021. Covid-19 and the Future of Zoos. In Les ateliers de l'ethique/The ethics forum. 
Pham H. 2021. Bu Dop District Forest Protection Department strengthens wildlife protection during the Covid-19 epidemic prevention and control period. Binh Phuong Province Forest Protection Department. Accessed 10 November 2021. http://kiemlam.binhphuoc.gov.vn/index.php? language=vi\&nv=news\&op=Tin-tuc-hoat-dong/Hat-Kiem-lam-huyen-Bu-Dop-tang-cuong-baove-dong-vat-hoang-da-trong-dot-phong-chong-dich-covid-19-578.html.

Pham TT, Dao TLC, Hoang TL, Bui TMN, Pham HL and Nguyen VD. 2018a. Opportunities and challenges in mobilizing finance to implement Vietnam's Forestry Development Strategy for 2006-2020. Occasional Paper 190. Bogor, Indonesia: CIFOR.

Pham TT, Bui TMN, Dao TLC, Hoang TL, Pham HL, Nguyen VD. 2018b. The role of Payment for Forest Environmental Services (PFES) in financing the forestry sector in Vietnam. Bogor, Indonesia: CIFOR.

Pham TT, Bui TMN, Pham HL, Nguyen VD. 2018c. The potential of REDD+ to finance forestry sector in Vietnam. Bogor, Indonesia: CIFOR.

Pham TT, Tang TBH, DHP, Nguyen TKN, Hoang Tuan Long. 2021a. COVID impacts on wildlife farms in Southern Vietnam. Technical Report. Bogor, Indonesia: CIFOR.

Phan H. 2020. Preventing the spread of Covid-19: Immediately ban the trade and consumption of wild animals. Thanh Nien Magazine. Accessed 10 November 2021. https://thanhnien.vn/ngan-dichcovid-19-lay-lan-cam-ngay-viec-buon-ban-tieu-thu-dong-vat-hoang-da-post939943.html.

Phu S. 2019. Step up the fight against violations of wildlife protection. Ho Chi Minh City Police Newspaper. Accessed 11 November 2021. https://congan.com.vn/tin-chinh/chinh-tri-thoi-su/daymanh-cong-tac-dau-tranh-vi-pham-ve-bao-ve-dong-vat-hoang-da_77321.html.

Phu S. 2020a. Confiscate 153 wild animals. Ho Chi Minh City Police Newspaper. Accessed 10 November 2021. https://congan.com.vn/doi-song/tich-thu-153-ca-the-dvhd-trong-thang-5_94243. html.

Phu S. 2020b. Confiscate many precious and rare wild animals. Ho Chi Minh City Police Newspaper. Accessed 10 November 2021. https://congan.com.vn/doi-song/tich-thu-nhieu-ca-the-hoang-daquy-hiem_89095.html.

Phu S. 2020c. 48 years in prison for illegal wildlife trade. Ho Chi Minh City Police Newspaper. Accessed 10 November 2021. https://congan.com.vn/song-theo-phap-luat/nhan-48-nam-tu-vibuon-ban-dong-vat-hoang-da-trai-phep_96016.html.

Phu S. 2020d. Selling wild animals, fined VND 100 million. Ho Chi Minh City Police Newspaper. Accessed 10 November 2021. https://congan.com.vn/doi-song/quang-nam_85953.html.

Public Security News. 2020. Latin America: Wildlife smuggling rages under COVID-19. Accessed 10 November 2021. https://cand.com.vn/Ho-so-Interpol/My-Latin-Buon-lau-dong-vat-hoang-dahoanh-hanh-theo-COVID-19-i582217/.

QUARTZ. 2020. Poachers are taking advantage of the pandemic to kill more animals. Accessed 1 November 2021. https://qz.com/1846069/poachers-take-advantage-of-coronavirus-to-kill-moreanimals/

Quoc D. 2020. Traffic police detected a passenger car carrying many wild animals. Ho Chi Minh City Police Newspaper. Accessed 10 November 2021. https://congan.com.vn/doi-song/csgt-phat-hienxe-khach-cho-nhieu-dong-vat-hoang-da_93144.html.

Roberts DL and Hernandez-Castro J. 2017. Bycatch and illegal wildlife trade on the dark web. Oryx 51(3): pp. 393-394.

Roe D, Dickman A, Kock R, Milner-Gulland EJ and Rihoy E. 2020. Beyond banning wildlife trade: Covid-19, conservation and development. World Development 136: 105121.

Roth A. 1 July 2020. Poachers kill more rhinos as coronavirus halts tourism to Africa. The New York Times. Accessed 1 November 2021. https://www.nytimes.com/2020/04/08/science/coronaviruspoaching-rhinos.html.

Rupani PF, Nilashi M, Abumalloh RA, Asadi S, Samad S and Wang S. 2020. Coronavirus pandemic (COVID-19) and its natural environmental impacts. International Journal of Environmental Science and Technology 17(11): 4655-4666.

Rutz C, Loretto MC, Bates AE, Davidson SC, Duarte CM, Jetz W, Cagnacci F. 2020. Covid-19 lockdown allows researchers to quantify the effects of human activity on wildlife. Nature Ecology \& Evolution 4(9): 1156-1159. 
Sánchez-Clavijo LM, Martínez-Callejas SJ, Acevedo-Charry O, Diaz-Pulido A, Gómez-Valencia B, Ocampo-Peñuela N, Ochoa-Quintero JM. 2021. Differential reporting of biodiversity in two citizen science platforms during Covid-19 lockdown in Colombia. Biological Conservation 256: 109077.

Sandalj M, Treydte AC and Ziegler S. 2016. Is wild meat luxury? Quantifying wild meat demand and availability in Hue, Vietnam. Biological Conservation 194: 105-112.

Sandbrook C, Gómez-Baggethun E and Adams WM. 2020. Biodiversity conservation in a postCovid-19 economy. Oryx: 1-7.

Save Vietnam's Wildlife. (forthcoming). Civet farming practices and their impacts on wild civets in Vietnam.

Sayer J, Sunderland T, Ghazoul J, Pfund JL, Sheil D, Meijaard E, Buck LE. 2013. Ten principles for a landscape approach to reconciling agriculture, conservation, and other competing land uses. Proceedings of the national academy of sciences, 110(21): 8349-8356.

Scherr SJ, Shames S and Friedman R. 2012. From climate-smart agriculture to climate-smart landscapes. Agriculture \& Food Security 1(1): 1-15.

Scrimpf MB, Des Brisay PG, Johnston A, Smith AC, Sánchez-Jasso J, Robinson BG ... and Koper N. 2021. Reduced human activity during Covid-19 alters avian land use across North America. Science Advances 7(39): eabf5073.

Sciortino R and Saini F. 2020. Towards a comprehensive narrative and response to Covid-19 in Southeast Asia. Social Sciences \& Humanities Open 2(1): 100058.

Sharun K, Tiwari R, Natesan S and Dhama K. 2021. SARS-CoV-2 infection in farmed minks, associated zoonotic concerns, and importance of the One Health approach during the ongoing Covid-19 pandemic. Veterinary Quarterly 41(1): pp. 50-60.

Shilling F, Nguyen T, Saleh M, Kyaw MK, Tapia K, Trujillo G and Ham E. 2021. A reprieve from US wildlife mortality on roads during the Covid-19 pandemic. Biological Conservation 256: 109013.

Shivaprakash KN, Sen S, Paul S, Kiesecker JM and Bawa KS. 2021. Mammals, wildlife trade, and the next global pandemic. Current Biology 31(16): 3671-3677.

Shreedhar G and Mourato S. 2020. Linking human destruction of nature to Covid-19 increases support for wildlife conservation policies. Environmental and Resource Economics 76(4): pp. 963-999.

Silva-Rodríguez EA, Gálvez N, Swan GJ, Cusack JJ and Moreira-Arce D. 2021. Urban wildlife in times of Covid-19: What can we infer from novel carnivore records in urban areas? Science of The Total Environment 765: 142713.

Siriwat P and Nijman V. 2018. Illegal pet trade on social media as an emerging impediment to the conservation of Asian otters species. Journal of Asia-Pacific Biodiversity 11(4): pp. 469-475.

Smith MKS, Smit IP, Swemmer LK, Mokhatla MM, Freitag S, Roux DJ and Dziba L. 2021. Sustainability of protected areas: Vulnerabilities and opportunities as revealed by Covid-19 in a national park management agency. Biological Conservation 255: 108985.

Spenceley A. 2020. COVID-19 and protected area tourism: A spotlight on impacts and options in Africa, World Trade Organization.

Stone MT and Nyaupane GP. 2018. Protected areas, wildlife-based community tourism and community livelihoods dynamics: Spiralling up and down of community capitals. Journal of Sustainable Tourism 26(2): pp. 307-324.

Swift L, Paul RH,Alexander CL, Diana JB. 2007. Wildlife Trade and the Emergence of Infectious Diseases. EcoHealth 4(1): pp. 25-30.

Symes WS, Edwards DP, Miettinen J, Rheindt FE and Carrasco LR. 2018. Combined impacts of deforestation and wildlife trade on tropical biodiversity are severely underestimated. Nature Communications 9(1): pp. 1-9.

Tam P. 2020. Go to jail for trading, transporting wild animals. Vietnam Agriculture Newspaper. Accessed 10 November 2021. https://nongnghiep.vn/vao-tu-vi-mua-ban-van-chuyen-dong-vathoang-da-d260221.html.

Ten DCY, Edinur HA, Jani R, Hashim NH and Abdullah MT. 2021. Covid-19 and the Malaysian zoo preventive measures readiness. J. Sustain. Sci. Manag 16: pp. 46-54. 
Thai A. 2021. Request to investigate the case of 5 langurs being shot dead. Vietnam Animal Welfare Association. Accessed 10 November 2021. https://baovedongvatvn.com/yeu-cau-dieu-tra-vu-5-cavooc-bi-ban-chet/.

The Jakarta Post. 2020. Covid-19: Indonesia steps up measures to anticipate influx of migrant workers returning home. The Jakarta Post. Accessed 1 November 2021. https://www.thejakartapost.com/ news/2020/03/31/covid-19-indonesia-steps-up-measures-to-anticipate-influx-of-migrant-workersreturning-home.html.

Thien N. 2020. Alarming the wildlife trade. Ho Chi Minh City Police Newspaper. Accessed 11 November 2021. https://congan.com.vn/vu-an/phong-su/bao-dong-nan-buon-ban-dong-vat-hoangda_102668.html.

Tien NH, Ngoc NM, Anh DBH, Huong ND, Huong NTT and Phuong TNM. 2020. Sustainable development of tourism industry in post Covid-19 period in Vietnam. Sustainable development 1(5).

TRAFFIC. 2020. The coronavirus pandemic and wildlife trade - TRAFFIC's perspective. TRAFFIC. Accessed 10 November 2021. https://www.traffic.org/news/the-coronavirus-pandemic-andwildlife-trade-traffics-perspective/.

Tran H. 2020. Covid-19 epidemic, an opportunity to protect wildlife. Quang Nam Newspaper. Accessed 10 November 2021. https://baoquangnam.vn/xa-hoi/dich-covid-19-co-hoi-bao-ve-dongvat-hoang-da-85178.html.

Tran T. 2010. Kon Tum: blatantly hunting wild animals. Tuoitre Online. Accessed 10 November 2021. https://tuoitre.vn/kon-tum-ngang-nhien-san-ban-thu-rung-365041.htm.

Tribe A and Booth R. 2003. Assessing the role of zoos in wildlife conservation. Human Dimensions of Wildlife 8(1): pp. 65-74.

Tylianakis JM, Herse MR, Malinen S and Lyver POB. 2021. Pandemic prevention should not victimize indigenous peoples and local communities. Conservation Letters e12813.

USAID Learns. 2020. Summary of the study of the status of wild animal trade prevention in Vietnam, Accessed 10 November 2021. https://pdf.usaid.gov/pdf_docs/PA00XCZX.pdf.

USAID WILDLIFE ASIA. 2021. Counter wildlife trafficking digest: Southeast Asia and China, 2020, Issue IV, May 2021. Accessed 10 November 2021. http://tiantianyule010.com/pdf/uwa\%20 cwt\%20digest $\% 20 \mathrm{iv} \% 202020$.pdf.

van Staden C. 2020. Covid-19 and the crisis of national development. Nature Human Behaviour 4(5): pp. $443-444$.

Van Vliet N, Moreno Calderón JL, Gomez J, Zhou W, Fa JE, Golden C and Nasi R. 2017. Bushmeat and human health: Assessing the evidence in tropical and sub-tropical forests. Ethnobiology and Conservation 6(3): pp. 1-45.

Walzer C. 2020. Covid-19 and the curse of piecemeal perspectives. Frontiers in Veterinary Science 7: 720.

Whitehead M. 2020. International wildlife trade is largely unregulated. The Veterinary Record 187(8): pp. 324-325.

Williams E, Carter A, Rendle J and Ward SJ. 2021. Understanding impacts of zoo visitors: Quantifying behavioural changes of two popular zoo species during Covid-19 closures. Applied Animal Behaviour Science 236: 105253.

World Bank. 2019. Taking stock: Recent economic developments of Vietnam. Special focus: Vietnam's tourism developments. World Bank.

World Travel and Tourism Council. 2019. The economic impact of global wildlife tourism - Travel and tourism as an economic tool for the protection of wildlife. Accessed 10 November 2021. https:// www.atta.travel/news/2019/08/the-economic-impact-of-global-wildlife-tourism-wttc/.

WWF. 2021. Covid-19 one year later: Public perceptions about pandemics and their links to nature China, Myanmar, Thailand, US, and Vietnam. Findings from 2021 Survey. Retrieved from https://wwfint. awsassets.panda.org/downloads/wwf_covid_19_one_year_later_update_single_pages_1.pdf

XiaoY, Guan J and Xu L. 2017. Traffic Wildlife Cybercrime in China. TRAFFIC.

Xu L, Yu DD, Ma YH, Yao YL, Luo RH, Feng XL and Yao YG. 2020. Covid-19-like symptoms observed in Chinese tree shrews infected with SARS-CoV-2. Zoological Research 41(5): pp. 517-526.

Zeiss CJ, Compton S and Veenhuis RT. 2021. Animal models of Covid-19. I. Comparative Virology and Disease Pathogenesis. ILAR journal. 
DOI: $10.17528 /$ cifor/008316

CIFOR Working Papers contain preliminary or advance research results on tropical forest issues that need to be published in a timely manner to inform and promote discussion. This content has been internally reviewed but has not undergone external peer review.

The Covid-19 pandemic has stirred up global and national concerns over human-wildlife interactions, unsustainable and illegal wildlife trade, ecosystem degradation and the need to transform both policies and practices in achieving effective conservation outcomes. As new policies on post-Covid-19 recovery are being developed, global and national policymakers and practitioners call for scientific and rigorous assessments on the effectiveness of past and current wildlife conservation policies and projects, and the impacts Covid-19 is having on them, to provide inputs for evidencebased decision-making processes. Our paper is one of many efforts aiming to respond to this call. Based on a literature review, case study approach, and national policy dialogue, this paper aims to understand the impacts of Covid-19 on wildlife conservation, opportunities for and challenges to enhancing the effectiveness of current and future conservation schemes, and to propose recommendations for post-pandemic conservation actions. 